NBER WORKING PAPER SERIES

\title{
SHORT, MEDIUM, AND LONG TERM CONSEQUENCES OF POOR INFANT HEALTH: AN ANALYSIS USING SIBLINGS AND TWINS
}

\author{
Phil Oreopoulos \\ Mark Stabile \\ Randy Walld \\ Leslie Roos \\ Working Paper 11998 \\ http://www.nber.org/papers/w11998
NATIONAL BUREAU OF ECONOMIC RESEARCH 1050 Massachusetts Avenue
Cambridge, MA 02138
January 2006

We gratefully acknowledge those individuals who helped make this research possible. These included: from the Department of Education, Citizenship and Youth --John Van Wallenghem, Richard Perrault, Carol Crera, Jean Britton, Ken Clark, and Shirley McLellan; from the Ministry of Family Services and Housing --Harvey Stevens, Grant Doak, Gudrun Fritz, and Jan Forster; and from the Ministry of Health -- Louis Barre. Stabile thanks the Canadian Institutes for Health Research for financial support. We also thank Florian Hoffman and Humaira Khair for excellent research assistance. The views expressed herein are those of the author(s) and do not necessarily reflect the views of the National Bureau of Economic Research.

(O2006 by Phil Oreopoulos, Mark Stabile, Randy Walld, and Leslie Roos. All rights reserved. Short sections of text, not to exceed two paragraphs, may be quoted without explicit permission provided that full credit, including $\odot$ notice, is given to the source. 
Short, Medium, and Long Term Consequences of Poor Infant Health: An Analysis using Siblings and Twins

Phil Oreopoulos, Mark Stabile, Randy Walld, and Leslie Roos

NBER Working Paper No. 11998

January 2006

JEL No. I1, I2

\begin{abstract}
We use administrative data on a sample of births between 1978 and 1985 to investigate the short, medium and long-term consequences of poor infant health. Our findings offer several advances to the existing literature on the effects of early infant health on subsequent health, education, and labor force attachment. First, we use a large sample of both siblings and twins, second we use a variety of measures of infant health, and finally we track children through their schooling years and into the labor force. Our findings suggest that poor infant health is a strong predictor of educational and labor force outcomes. In particular, infant health is found to predict both high school completion and social assistance (welfare) take-up and length.
\end{abstract}

Phil Oreopoulos

Department of Economics

University of Toronto

150 St. George Street

Toronto, ON M5S 3G7

Canada

and NBER

oreo@economics.utoronto.ca

Mark Stabile

Department of Economics

University of Toronto

150 St. George Street

Toronto, ON M5S 3G7

CANADA

and NBER

mark.stabile@utoronto.ca 


\section{INTRODUCTION}

Infants born in poor health, as measured by low and very low birth weights and low APGAR scores, have lower chances of survival, and may also experience further health and social difficulties later in life (Conley, 2003). Low birth-weight babies are also increasingly expensive to treat in hospital. Almond et al (2005) calculate that among babies weighing 2000 grams, an additional 450 grams is associated with a $\$ 10,000$ savings in hospital charges for inpatient services. As such, understanding the causes and consequences of poor infant health has been a primary concern of both the medical and health policy literature for some time.

Medical advice to expecting mothers on how to prevent low-birth weight, including refraining from smoking and seeking pre-natal care, is centered around the notion that preventing low birth-weight will improve both the life chances of the child and chances of future success. Researchers have also noted the potential to reduce hospital costs significantly through inexpensive pre-natal interventions aimed at reducing low birth-weight in particular (Almond et al, 2005). Program evaluations on Medicaid expansions in the U.S. (Currie and Gruber, 1996) and the institution of national health insurance in Canada (Hanratty, 1996) have also focused on improved pre-natal treatment and its potential effects on infant health, providing further evidence of the policy importance of, and potential benefits associated with improving infant health.

As noted in Almond et al (2005) interventions aimed particularly at reducing lowbirth weight are premised on the notion that low birth-weight in particular is the cause of poor health and related outcomes in the future, and not simply a marker and correlate of 
such problems. While interventions and public policy aimed at improving overall infant health, including reducing the incidence of low-birth weight, are likely to have both short and long term benefits, a clearer understanding of the causes and consequences of poor infant health can only help to improve the efficacy of both health care and public policy. A considerable body of research attempts to quantify the effects of early infant health on both early childhood survival and on future health, education, and social outcomes. Conley, Strully, and Bennett (2003), for example, examined the effects of birth weight for both fraternal and identical twins on both neonatal and post-neonatal mortality. Using data from the Matched Multiple Birth Data Set, 1995-1997, which contains data on 271,000 twins, they conclude that birth weight differences between twins affects infant mortality and that this effect is stronger for fraternal than identical twins. Almond, Chay, and Lee (2005) examine the relationship between low birthweight, low APGAR scores, and mortality in the first year of life. Using a large sample of twin births from the National Center for Health Statistics, they show that, while both birth-weight and APGAR scores are strongly related to infant mortality across families, the relationship between birth-weight and infant mortality significantly decreases when differences between twins are examined. In contrast, the relationship between APGAR scores and infant mortality remains strong both across families and within twin pairs. Both papers note that, while twin samples can be extremely helpful in eliminating unobserved heterogeneity across families, the resulting sample is somewhat unique in that twins tend to be of lower weight than the average in the singleton infant population. 
A second stream of social science literature has used twin studies to examine the longer-term effects of birth-weight on health and education. Behrman and Rosenzweig (2004) use twin data from the Minnesota Twins Registry to examine the effects of low birth-weight on the educational attainment and adult health of women. They find that increasing birth-weight increases schooling attainment by about one third of a year and that this effect is stronger within twins than across children of different families. Conley, Strully, and Bennett (2003) examine the effects of low birth-weight on high-school graduation and placement in special education. Using the Panel Study of Income Dynamics, Conley et al exploit within sibling variation to examine the longer-term consequences of low birth-weight, finding that the effects of low birth-weight on timely high-school graduation are more pronounced among siblings than across families. Finally, Black et al (2005) use a sample of Norwegian twins to examine the long-run consequences of low birth weight. Their evidence confirms that low birth weight is not a good predictor of infant death within twin-pairs. However, they do find long-term effects of low birth weight on cognitive outcomes, educational outcomes, and on earnings.

Our paper tries to reconcile some of the disparate results of previous work in the following ways: First, it uses an administrative sample of both siblings and twins to examine the effects of infant health on mortality within one year. Comparing sibling findings and twin findings allows us to overcome concerns that twins are a select sample of the population and that inference from this sample is not, therefore, generalizable to the broader population. Second, tracking both siblings and twins through school and into their early experiences in the workforce provides longer-term evidence for both groups, including educational outcomes, health care costs, and social assistance receipt. Third, a 
variety of infant health measures, including birth-weight, APGAR scores, and gestational length, are used to contrast the effects of these measures on outcomes and to reconcile and expand the findings of other research using multiple measures of infant health. Gestational length is an important determinant of low birth weight, one which twin only studies are unable to examine. Finally, using a sample of children with uniform access to health insurance further corrects for any potential unobserved heterogeneity within families across siblings that might not be captured in sibling fixed effects models and offers an interesting comparison with a U.S. sample lacking universal coverage.

Our findings offer several advances to the existing literature on the effects of early infant health on subsequent health, education, and labour force attachment. First, we confirm earlier results by Almond et al, which show that the effect of infant health as measured by birth-weight less than $2500 \mathrm{~g}$ largely disappears when looking at within twin variation. The 5 minute APGAR score, and measures of very low birth-weight (less than $1500 \mathrm{~g}$ ) are stronger predictors of infant mortality within one year than birth-weight for twin samples. However, we find that within sibling pairs APGAR, low birth-weight, and gestational age predict infant mortality within one year, even though we continue to account for unobserved heterogeneity across families. Second, infant health is found to predict both high school completion and social assistance (welfare) take-up and length. We find evidence of longer-term consequences of infant health both across families, within siblings, and within twin pairs, although different measures of infant health predict outcomes differently. Interestingly, we find weaker evidence of the longer-term effects of infant health on either cognitive ability as measured by language arts test scores or longer-term physician visits and costs. Overall, we conclude that there are indeed long- 
term consequences of poor infant health, and that a better understanding of these consequences can be determined by examining a variety of infant health measures and by examining the variation both within families and within twin pairs. The implications of these findings is that reductions in poor infant health will lead to lower mortality, greater human capital accumulation, and lower welfare usage.

The paper proceeds as follows: Section 2 describes the data used in the analyses. Section 3 outlines our empirical methodology. Section 4 presents our results, and section 5 concludes.

\section{DATA}

The data are from the Population Health Research Data Repository at the Manitoba Centre for Health Policy (MCHP). Our main data match hospital records at birth to other administrative records on education, physician visits, and social-assistance take-up. Hospital records at birth were checked against Manitoba Health registry data (which is coordinated with federal Vital Statistics files). The sample includes 99.6 percent of all children born in Manitoba in 1978-1982 and 1984-1985. The cohort born in 1983 was not included because grade 12 provincial tests were not given in the school year 2000/2001 (when the 1983 birth cohort would be expected to be in grade 12). Health, educational and social assistance outcomes are tracked up to $2004{ }^{1}$

The birth data originate from Manitoba Health hospital records. Since 1970, the registry attaches to every birth a family identification number (called the Registration

\footnotetext{
${ }^{1}$ In Canada, welfare is more commonly referred to as social assistance. For consistency, we maintain this terminology.
} 
Number or REGNO), which links the infant to the 'family head', usually the father.

When an individual turns eighteen years old, he or she receives his or her own REGNO.

On marriage, a female receives the REGNO of her husband. Both mother's identification number (an encrypted PHIN or Personal Health Identification Number) and REGNO are used to define siblings. Children born to the same mother but different fathers and to the same father but different mothers (half siblings) are included as siblings. Several checks on this algorithm as applied to the seven years of birth cohorts (looking at missing data, the number of children designated as having the same mother and father, and complicated blended families) have indicated it to be highly accurate.

Two siblings with the same birth date are designated as twins. The birth records do not allow us to distinguish between monozygotic and dizygotic twins. Based on earlier descriptive studies [e.g. Conley et al, 2003], our twins data are likely comprised of roughly 25 percent monozygotic pairs and 75 percent dizygotic pairs.

The postal code from the family head's address identifies the street or building where the family lives. The address of the family is updated about every six months. To proxy for general social economic background, family income in the 2001 Census was aggregated and averaged over Enumeration Areas, which were in turn matched to corresponding postal code addresses in our sample. Enumeration areas contain a population of about 400 to 700 persons. The areas were ranked from highest to lowest income and then grouped into five population quintiles. Mustard et al. (1999) and Roos et al. (2005) show a substantial correlation between self-reported household income, not available in our data, and a person's neighborhood average income. 
Table 1 presents descriptive statistics of the infant health measures recorded on the hospital records and used in our study: birth weight (in grams), gestation (in weeks), and 5 minute APGAR score (on a 10 point scale). Means, standard deviations, and percentiles for these measures are shown for the full sample of births between 1979 and 1985. These statistics are also shown for the subset sample of births with at least two siblings identified within this cohort range and the subset sample of twins. The sibling sample excludes twins.

The frequency distributions of these variables compare similarly with those generated from nationally representative samples of Canada or the United States. The mean birth weight among the full sample is about 3,500 grams. Twins weigh about 950 grams less and are born about three weeks earlier. About 7 percent of the full sample is born low birth weight, defined as weighing less than 2,500 grams. In the analysis below, we explore not only the effects of being born less than 2,500 grams and less than 1,500 grams, but also the effects of being born below average birth weight, between 2,500 to 3,000 grams and between 3,000 to 3,500 grams. Gestation before birth typically takes about 40 weeks. Preterm births are often defined as births before 37 weeks gestation; there are 7 percent preterm births in our full sample. Late births occur after 41 weeks.

The APGAR score summarizes 5 vital sign conditions at birth. Heath care providers assess an infant's heart-rate, respiration, muscle tone, reflex, and color and assign values of 0,1 , or 2 for each category, with the best possible total score equaling 10. A score less than seven often triggers additional action to stabilize conditions. A score of 7 to 10 is considered normal. As shown below, lower 5-minute APGAR scores 
even within this normal range affect subsequent educational outcomes and social assistance take-up.

The typical variation in these infant health measures between a pair of siblings or a pair of twins is about 55 to 70 percent of the typical variation between any randomly chosen infant pair. Column 2 of Table 1 shows the standard deviations. Column 3 shows the standard deviations between siblings and twins. These amounts are the standard deviations of the residuals generated after regressing the health measures on a set of family fixed effects. The standard deviation for APGAR scores is about 0.92 over the full sample and 0.65 within families. The standard deviation for gestation is about 2 weeks and 1 week between siblings. The within family standard deviation of birth weight is still 314 grams between siblings, and 202 grams between twins. In perspective, Almond, Chay, and Lee (2005) report that the average difference in birth weight between a newborn with a mother who smokes and one with a mother who does not is 285 grams. ${ }^{2}$ The average difference in gestation is 0.3 weeks, while the average difference in 5 minute APGAR score is 0.07 . Our main analysis uses within family variation in infant health to explore short and long run differences in social economic outcomes. Column 3 indicates considerable variation within families to work with in exploring later outcome differences.

We observe differences in infant health across both siblings and twins for several reasons. Between siblings birth weight can differ due to both gestational length and differences in intrauterine growth retardation (IUGR). Between twins differences in birthweight are attributable to differences in IUGR. Twin studies have emphasized that much

\footnotetext{
${ }^{2}$ These figures are for the sample of Pennsylvania singletons born between 1989 and 1991 . The means, standard deviation, and percentiles reported in Table 1 are similar to those reported by Almond, Chay, and Lee for their Pennsylvania sample.
} 
of the literature has focused on differences in IUGR, despite the fact that gestational length accounts for a significant percent of the low-birth weight infants. One possible reason for this, as noted by Almond et al (2005) and reported in Goldenberg and Rouse (1998) is that there is little medical evidence on how to effectively increase gestational length, whereas there are widely accepted policy interventions aimed at IUGR (reducing smoking and ensuring appropriate nutrition during pregnancy, are the most common of these). APGAR scores differ between both siblings and twins. The test was initially designed to measure whether infants required immediate medical care, and has been shown to be highly correlated with infant mortality (Almond et al, 2005) ${ }^{3}$. After testing whether the infant health measures presented here are good predictors of death in the first year, we then consider, conditional on survival, whether they are also predictors of poor health later in life and potentially measures of cognitive ability and human capital as well.

Table 2 lists the health and socioeconomic outcomes explored in our paper. The infant mortality variable comes from matching births and deaths from the Manitoba Vital Statistics over the first year of life. The variable takes on the value of 1 if a birth is matched to a death in the first year, and zero otherwise. A death between ages 1 and 17 is similarly recorded.

The other outcome variables came from administrative data on physician costs, education, and social assistance. These data are available only for Manitoba residents. The analysis of the effects of infant health on these longer-term outcomes, therefore, is conditional on survival and conditional on remaining a resident in the province. We

\footnotetext{
${ }^{3}$ The definition and purpose of the APGAR were obtained from the NIH web site at: http://www.nlm.nih.gov/medlineplus/ency/article/003402.htm
} 
focus on estimating the long-term effects of infant health for those born in Manitoba and living in the province at least until they reach 17.5 years old. Table 2 indicates that 24 percent of our original sample of births in Manitoba between 1979 and 1985 either died or left the province before this age. We shall document that health at birth does indeed affect mortality before age 17 , even after one year, but it does not affect mobility. For all outcome measures except mortality and mobility, we condition on the sample of those remaining in Manitoba at least until age 17.

The Manitoba Repository data record hospital discharge abstracts and physician claims extending back to 1970. Physician claims include diagnostic information and are primarily reimbursed on a fee-for-service system. We summarize adolescent health by summing the number of physician visits recorded between ages 12 and 17 . This measure counts multiple physician interactions during one encounter (for example, from seeing one doctor at an emergency room and another while obtaining an x-ray) as one visit. Over 90 percent of this population contacts a physician over a two-year period and the average visit rate is more than four visits per year.

The birth registry can be matched to all school enrollment records in Manitoba. The enrollment records are used to determine whether a student has attained Grade 12 by age 17 . Not attaining grade 12 by this age could indicate a student has dropped out or been held back in a grade at least once. We use this variable as our main education attainment measure because our birth sample is matched to enrollment records only until age 17 . Students may not have reached Grade 12 because they have been held back. On the other hand, many students held back are more likely to drop out. Our 
measure proxies as an overall indicator for being at risk of ending up with a low level of education attainment.

We also match our sample to information from provincial language arts standards tests taken in grade 12 . These tests contribute 30 percent to the students' final course grade. Individuals pass the language arts test by scoring 50 percent or more on a comprehensive exam. For each birth cohort, we record the test score in 5 percentage point categories (19 in total) in the year that most students write the test. For those not writing, we impute a test score by defining additional categories and ranking them below the lowest score attained by the group writing the test. These additional categories, listed by highest to lowest rank are: absent (about 1 percent of each birth cohort sample); In grade 12 but not tested (about 8 percent); In grade 11 or lower (about 19 percent), Not enrolled (about 2 percent), and Withdrawn from School (about 10 percent). Following methods forwarded by Mosteller and Tukey (1977) and Willms (1986), we then compute a standardized score for each individual by assuming an underlying logit distribution, which is divided into pieces according to the percentage of cohort members in each category. Scores are calculated separately for each birth cohort because of small changes in the categories available and in the percentage distribution each year. In a typical year, the highest scorers are given an index score of 2.96, while those withdrawn from school are given a score of -1.84 . The logit transform produces an index with an overall mean of zero and a standard deviation of one. The ordering on this index corresponds closely with the student's probability of graduation.

Finally, the sample of Manitoba residents is matched to monthly social assistance records up to March 2004. Our youngest birth cohort can only be followed for about a 
year after the age of 18 . The oldest cohorts are followed from 18 to 25 . Nine percent of our sample received some social assistance before April 2004. Fixed effects for birth cohort in our regressions will absorb average differences in take-up due to this truncation of information for some cohorts. In case infant health may also affect the length of time on social assistance, we focus on the number of months individuals in our sample used these services. The average number of months on social assistance over our entire sample is 2.1 .

\section{EMPIRICAL METHODS}

We estimate models of the effects of early infant health on 1 year infant mortality as follows:

$\inf$ mort $_{i j t}=\alpha+\beta \inf$ health $_{i j}+X_{i j}+\delta_{j}+\tau_{t}+\varepsilon_{i j t}$

Where infmort represents death within 1 year of the date of birth. $i$ indexes the child, $j$, the family, and $t$ the year. $X$ measures family or individual specific controls such as marital status, sex of the child, mother's age at birth, and, in some cases, household income measured at the zip code/ postal code level. We also include a set of dummies for the birth order of the child within each family size to completely control for any effects of both birth order and family size. ${ }^{4}$ The $\tau_{\mathrm{t}}$ are year of birth fixed effects to account for any

\footnotetext{
${ }^{4}$ Several studies point out that family size correlates with education and other social economic outcomes. Black, Deveraux and Salvanes, 2004, also find important differences in outcomes depending on birth order. We control for these differences with family size and birth order fixed effects, in case these variables also relate to infant health. Excluding such controls does not change our baseline results in significant ways.
} 
differences by year of birth of the child. The $\delta_{\mathrm{j}}$ are family fixed effects which, as we outline in greater detail below, are included in some specifications.

Our primary parameter of interest is $\beta$, which is the coefficient associated with our estimate of the effect of early infant health. As discussed above, we use three different measures: birth-weight, 5 minute APGAR score, and gestational length in weeks. Our main analysis classifies these infant health measures into categories and uses dummy variables to estimate possible non-linear effects of infant health. This approach helps uncover more detailed relationships between infant health and our outcome measures. For example, education attainment may differ by birth weight only for the small fraction born weighing less than 2,500 grams and surviving. In this case, a linear regression model would not adequately capture this relationship. For APGAR score, we estimate effects at birth by comparing scores of 6 or less, 7 to 8 , or 9 , to a score of 10 . For birth weight, we group infants by whether they weigh 1,000 grams or less, 1,001 to 1,500 grams, 1,501 to 2,500 grams, 2,501 grams to 3,000 grams, 3,001 to 3,500 grams, and 3,501 grams or more. For gestation, we compare normal gestation length, between 40 and 41 weeks, to infants born with less than 37 weeks gestation, 37, 38, 39 weeks of gestation, and 42 weeks or more. To facilitate discussion and compare with some earlier studies, results from the linear specification are presented in the Appendix.

For each measure of infant health we estimate 5 models: OLS using our entire sample, OLS using the sample of children with siblings, OLS using the sample of twins in the data, the sibling sample including family fixed effects $\left(\delta_{\mathrm{j}}\right)$ and finally the twin sample including family fixed effects. 
Our estimates of equation (1) serve two purposes. First, we are able to replicate the results found in Almond et al (2005), contrasting OLS and twin models with family fixed effects, using a smaller sample of Canadian children. The differences using between family and within family variation found in that research are shown to hold for this sample of Canadian children as well. Second, we are able to expand on the Almond et al analysis of the effects of infant health on one-year mortality by estimating fixed effects models using variation in infant health across siblings instead of across twins.

In addition, we estimate alternate versions of equation (1) using the other outcome measures described above, including: whether the child was held back a grade, the child's language arts test scores measured in grade 12, whether the child dropped out of high school before graduation, and whether the child was on social assistance. Thus we are able to apply the same OLS, twin, and sibling analyses to a variety of longer-term measures of child health and social outcomes.

\section{RESULTS}

Table 3 shows the effects of our measures of infant health on infant mortality (death before age 1). The subsequent tables presenting results with different outcome variables have a similar structure. Column 1 displays the coefficients on the infant health categories for the full sample of singletons and siblings, without family fixed effects. These results are from the linear probability model for whether an infant died in the first year regressed on the infant health dummy variables, plus controls for mother's marital 
status, gender of child, and a complete set of dummy variables for all family size and birth order combinations. The second column shows the same regression, but for the subset sample of births with at least one other sibling identified within the birth cohorts 1979 to 1985 (but excluding twins). In the third column, the coefficients presented correspond to the regression model that now includes family fixed effects. The fourth and fifth columns show the results among twins, without and with family fixed effects respectively.

The first panel shows the results defining infant health by 5 minute APGAR score. Infants born assessed with an APGAR score below 7 are about 26 percentage points more likely to die within one year than those with APGAR scores of 10, and 31 percentage points more likely to die among the sibling sample. This relationship holds when we use only differences between siblings in column 3. The coefficient remains virtually unchanged. However, after adding family fixed effects in the twin sample, the coefficient falls by about two-thirds. The relatively higher association between APGAR and early death is far less severe for those with scores of 7 or 8 . While such assignments are not normally considered indicators of critical need, non-twin siblings in this category are about 1.9 percentage points more likely to die within a year than other siblings with scores of 10. For twins, however, this relationship drops by a third, and is measured less precisely because of the smaller sample size. The results also suggest only a minute difference in infant mortality between infants with APGAR scores of 9 versus 10.

The second panel presents the same set of results, but using birth weight instead of APGAR categories. Interestingly, the same contrast in results between the sibling and the twins samples arises when we compare the effects of very low levels of birth weight 
on infant mortality with and without fixed effects. The estimated effects of low birth weight slightly increase after adding the family fixed effects for the sibling sample. Even for infants born between 2,500 and 3,500 grams - below average weight but not typically considered low birth weight -- there is about a 1 percentage point higher risk of death within one year. The estimated effect associated with weighing less than 1,500 grams falls by about two-thirds when comparing twins from the same family compared to using cross variation of the non-twin sibling sample. Similar results were found by Almond, Chay, and Lee (2005), who focus on twins exclusively.

Variation in infant health between twins cannot be due to changes in socioeconomic circumstances of the parents between births. Changes in such circumstances over the 1 to 7 year period in our sibling sample do not seem large enough to explain the different estimates, especially since the coefficients do not fall at all after adding the fixed effects (the twins results suggest a downward omitted variable bias). Another explanation is that twin birth weight variation cannot result from differences in gestation, but it certainly can with the sibling sample. The last panel indicates siblings born premature are significantly more likely to die in one year than another sibling not born premature. A sibling born 37 weeks since conception faces a 1.4 percentage point higher chance of infant mortality than another sibling born between 40 and 41 weeks since conception. We also find slightly higher chances of infant mortality from 39 weeks gestation. Thus, one possibility to explain the different estimated effects from low birth weight and low APGAR score between non-twin siblings and twins is gestation, an important source of variation correlated with these measures of infant health but left out from the between twins analysis. 
Extending the analysis on child death out to the first 17 years of life we continue to find an effect of both low APGAR scores and low birth weight on survival when we examine children across families and between siblings within families (Table 4). Indeed, the coefficients on birth weight between 1000 and 2500 grams actually increase once we include family fixed effects, and the coefficients on the lowest APGAR scores remain relatively stable. Using the twin sample, however, we find no evidence of a negative relationship between infant health and death up to age 17. In fact, the coefficient on APGAR scores between 7 and 8 is the wrong sign and marginally significant. Given the drop in predictive power within twins for our one-year mortality rate estimates, it is perhaps not surprising that we do not find results with twins for mortality 17 years out. On the whole, however, we take these results as evidence that infant health continues to be a strong predictor of mortality both across and within families even up to age 17 .

Table 5 indicates no important effects from infant health on Manitoba emigration. The OLS results with the full sample indicate a small correlation between poorer infant health and moving away from the province before age 17. But the point estimates gravitate towards zero after including the family fixed effects regardless of which measure of infant health is used. Our results suggest that once we control for family fixed effects, our estimates on the impact of infant health on later outcomes among Manitoba residents do not appear to be biased from some fraction of our sample leaving the province.

Conditional on survival until age 17, we find little evidence of significant effects of infant health on physician utilization between ages 12 and 17. Table 6 displays the estimates of the effects of APGAR score, birth weight, and gestation on total physician 
visits between these ages, with and without including family fixed effects. The dependent variable here is number of physician visits between the ages of 12 and 17 . We find little consistent evidence here to support a relationship between infant health and physician visits 12 to 17 years later. Although we do find some evidence of a greater number of visits within twin families for those children with birth weights between 1000 and 1500 grams, the majority of the coefficient estimates are insignificant and some are also the wrong sign.

Table 7 shows the results of the language arts standards test for the sample of Manitoban residents at age 17. Recall that for the approximately 30 percent of residents who did not write the test, the score is imputed by ranking these individuals lower than those writing the test and categorizing them by enrollment and attainment categories (e.g. withdrawn from school or held back). A score is given to each associated test score and education attainment category using a standardized logit transformation weighted by the population size in each group.

Columns 1 and 2 indicate a clear positive correlation between infant health and the language arts test measure. For example, a low birth weight child averages a score about 0.23 standard deviations below a child born weighing above 3,500 grams. APGAR scores less than 8 and gestation lengths less than 38 weeks are also associated with significantly lower grade 12 test scores. The relationship weakens notably after adding the family fixed effects. The point estimates for birth weight and APGAR score are all still negative, but many are no longer significant. Siblings given an APGAR of 6 or less receive a test score about one-tenth of a standard deviation lower than a sibling with a 10 . We also find indications of small, but in some cases significant, lasting effects on test 
scores from being born low birth weight, even among youths born weighing between 2,500 and 3,500 grams (only slightly below the average). The negative coefficients associated with gestation of less than 37 weeks without fixed effects become close to zero once fixed effects are added. All the point estimates for the gestation results are very small and insignificant. The large standard errors around the estimated effects for the twins sample (with or without fixed effects) make it difficult to draw any insight from the analysis using gestational length here.

While our results for language arts test scores are mixed, our results examining high school attainment suggest long-lasting effects of infant health. Table 8 shows the estimates for the effects of infant health on reaching grade 12 by age 17. An individual may fail to reach this grade because she either dropped out or repeated at least one earlier grade. The sibling fixed effects analysis in column three indicates a substantial impact on grade 12 attainment from infant health. Moving from the results with no family fixed effects to those that include them show only a small fall in the coefficients.

A newborn assessed with an APGAR score of 6 or less, for example, has a 7.4 percentage point lower probability of reaching grade 12 by age 17 compared to a youth born with an APGAR of 10 (column 2). When family fixed effects are added (column 3), the estimated effect drops to a 4.1 percentage point difference in the probability of reaching grade 12 by this age. Siblings with APGAR scores still considered normal but below average ( 7 or 8 ) are 2 percentage points more likely to drop out or repeat a grade. A similar story holds when looking at birth weight. Students born with low birth weights between 1500 and 2500 grams, and who survive until age 17 are about 8 percentage points less likely to be enrolled in grade 12 than those born weighing 3,500 
grams or more. The chances of infants attaining Grade 12 by age 17 are severely affected by being born weighing less than 1500 grams. The gestation results are also strong and significant. Premature siblings born in 36 weeks or less are 4.0 percentage points less likely to have reached grade 12 by age 17 than those born in 40 to 41 weeks. Negative effects on this measure of educational attainment among those born in 38 or 39 weeks are also detected. A sibling born after 38 weeks gestation is 2.5 percentage points less likely to be in grade 12 at age 17 than another sibling born under 40 weeks gestation.

Table 9 shows the estimated effects of infant health on the probability of receiving any social assistance between the age of 18 and the last year for which we have data (2004). Given that individuals in our birth cohorts were born between 1979 and 1985, only 8.9 percent of our sample ever received social assistance over this period. The least-squares results without family fixed effects indicate a substantial relationship between poor infant health and receiving social assistance. APGAR score, in particular, strongly predicts take-up. A young adult given an APGAR of 6 at birth has a 5 percentage point higher probability of receiving welfare than a contemporary given an APGAR of 10. Individuals with APGAR scores between 7 and 9 also have a higher likelihood of receiving social assistance. These effects are closer to zero once the family fixed effects are added in column 3. The point estimates are somewhat noisy, but they suggest that the causal effects of APGAR score on welfare use, independent of family circumstances that correlate with this score, are lower than predicted by the strong effects estimated using the cross-family variation. Interestingly, the estimates from the smaller sample of twins do suggest a big effect. From column 5, a twin given an APGAR of 7 
stands an 11.0 percentage point higher probability of receiving social assistance than does her other twin with an APGAR of 10.

The effects of birth weight on social assistance take-up also dissipate once family fixed effects are included in the model. The least-squares results in column 2 indicate a strong escalating relationship between being born low birth weight and receiving social assistance. The point estimates fall substantially in column 3 from including the family fixed effects. While, once again, the estimates for this outcome variable are imprecise, the standard errors are small enough to rule out that the estimates are equal to those without the fixed effects, while not ruling out the effects are zero. The twins results, like the case with APGAR scores, are more suggestive of a long-lasting effect from infant health.

The gestation results without fixed effects indicate a significant relationship among youths born after less than 38 weeks gestation. These coefficients, however, all drop close to zero (and are imprecisely measured) after adding in family fixed effects.

In an attempt to increase the variance of social assistance use in our sample, we also look at months on social assistance between age 18 and (up to) age 25. Table 10 presents these results. The mean number of months on social assistance in our sample of siblings is 2.1. The results are also somewhat noisy, but generally suggest a continued link between our infant health measures and social assistance use. Birth weight appears to affect not only take-up but also duration of social assistance. The coefficients for the effects of low birth weight on months on social assistance using family fixed effects are about one-half to two-thirds the size of those without the fixed effects. The estimates for the average association between being born 1,500 to 3,000 grams and social assistance 
use are significant, and we can reject the hypothesis that all the estimated effects are zero or less. The coefficients from the twins sample with family fixed effects included, all suggest a long-lasting effect of poor APGAR score or birth weight on months on social assistance. The APGAR score results are not significant, but the implied effects of birth weight are large, as they are when looking at only social assistance take-up (in the previous table).

In Table 11, we reexamine our main sibling results for a sub-sample of siblings less than 2 years and 3 years apart. A threat to validity in the siblings analysis comes from changes to family or environmental contexts in between births that could account for differences in socioeconomic outcomes. By looking at a sub-set of siblings closer in age, fewer changes in family circumstances that may affect these outcomes are likely to occur. The coefficients on the estimated effects of APGAR scores, birth weight, and gestation on infant mortality largely remain intact after looking only at siblings less than 2 years apart. The estimates with family fixed effects remain quite similar to the estimates without them and indicate a strong relationship and suggest a significant causal relationship between these measures of health at birth and one year mortality. It is worth pointing out again that this contrasts with the twins results, where the estimated effects fall by as much as two-thirds when accounting for family factors common between twins.

Table 12 shows the analysis for grade attainment outcomes between the sample with all siblings and the one with siblings less than 2 years apart. The sub-sample is onefourth the size of the full sample. Yet, for birth weight, the results are remarkably stable. Low birth weight siblings are approximately 10 percentage points less likely to attain Grade 12 by age 17 . Even those born between 2500 and 3500 grams are 2 to 5 
percentage points less likely to attain Grade 12 compared to those born weighing more than 3500 grams. The estimated effects from being born premature or with a low APGAR are measured less precisely with the sub-sample of siblings close apart, but the results generally point to the same conclusions about impact of these measures on grade attainment, with and without including family fixed effects. For more precision, we also include the results for the sample of siblings less than 3 years apart in columns 5 and 6 . Low APGAR scores and gestation significantly impede high school grade progression.

Table 13 repeats the analysis, but for social assistance take-up outcomes. The full sample results suggest significant effects of low birth weight on months receiving social assistance after age 19, as does the sample of siblings less than 3 years apart. The standard errors around the point estimates for the smaller sample of siblings less than 2 years apart prevent definitive conclusions. The APGAR results include a non-intuitive results that those born with an APGAR score of 9 instead of 10 are slightly less likely to end up on social assistance, while those born with an APGAR score of 7 or 8 are more likely. None of the gestation results are significant.

We end our analysis by considering whether our estimated effects of infant health on subsequent outcomes differ by family background. Columns 1 and 2 of Table 14 repeat the previous sibling sample results for the estimated effects of infant health on one-year mortality, with and without family fixed effects. In the next two columns, we show the results for the same model, but from using the sample of only births from parents in residential areas where family incomes are among the first quintile. The results among the bottom fifth group of families still reveal quite similar point estimates compared to those from the full sample. For example, among children with parents from 
the lowest residential income quintile, an APGAR score of 7 or 8 for one sibling is associated with a 2.3 percentage point higher likelihood of death within one year than another sibling given a 5 minute APGAR score of 10. Columns 5 and 6 include results for the sample of births with parents from the bottom two residential income quintiles. This increases the sample, while still focusing on families from poor social-economic backgrounds. In general, we find no substantial differences in the estimated effects of infant health on mortality comparing these more disadvantaged groups with the entire population of births.

Table 15 shows the results by residential income quintile for whether an individual born in poor health is more likely to have been held back or dropped out by age 17. Here the imprecision of the estimates when using the smaller sample size of the lower quintiles makes it more difficult to make comparisons with the full sample. The point estimates for the lower quintile sample in columns 3 and 4 are higher than those for the full sample in almost all cases, but not by much. In general, we conclude that there is no strong evidence that the effects of infant health on high school attainment are any worse among families from lower income backgrounds. The estimates with the two lower quintiles also are not significantly different from the full sample results.

Finally, Table 16 displays the quintile results for months on social assistance. The estimates are not suggestive of any differences between the lower quintile groups and the population. However, the estimates are somewhat imprecise. Overall, our results by quintile suggest that the short, medium, and longer-term effects of infant health are not confined to a single quintile, but rather are uniform across the population. 


\section{CONCLUSIONS}

We use a cohort of births from a single Canadian province to examine the short, medium and long-term effects of poor infant health. Our results both confirm and extend recent work on the effects of infant health on survival and future measures of health, human capital, and labor force attachment.

Using three measures of infant health: birth-weight, APGAR scores, and gestational length, we find that poor infant health predicts both mortality within 1-year, and mortality up to age 17 . These results hold both across families and between siblings within families. Consistent with results in Almond et al (2005), differences in infant health within families but between twins pairs lead to much smaller differences in both 1 year and 17 year mortality rates. This drop in the estimated effects occurs for twins but not for siblings.

We also find that infant health is a strong predictor of educational and labor force outcomes. In particular, infant health is found to predict both high school completion and social assistance (welfare) take-up and length. We find evidence of longer-term consequences of infant health both across families, within siblings, and within twin pairs, although different measures of infant health predict outcomes differently. Interestingly, we find less evidence of the longer-term effects of infant health on either cognitive ability as measured by language arts test scores or longer-term physician visits.

Our evidence, along with a growing body of literature in this area, confirms the importance of early childhood health as a predictor of future outcomes. Examining 
differences across families, between siblings, and between twin pairs can help inform both the medical literature and public policy with regards to the most effective way to improve childhood health and hence future outcomes. 


\section{REFERENCES:}

Almond, D, Chay, K., and David Lee, “The Costs of Low Birth Weight”, Quarterly Journal of Economics, 120(3), 2005.

Behrman, J., and Mark Rosenzweig, "The Returns to Increasing Body Weight," Penn Institute for Economic Research Working Paper 01-052, 2001.

Behrman, J., and Mark Rosenzweig, "The Returns to Birth Weight,” Review of Economics and Statistics, 86, 2004.

Black, S. Devereux, P., Kjell Salvanes, "From the Cradle to the Labor Market: The Effect of Birth Weight on Adult Outcomes,” NBER Working Paper 11796, 2005.

Black, S., Devereux, P., and Kjell Salvanes, "The More the Merrier? The Effect of Family Size and Birth Order on Children's Education," The Quarterly Journal of Economics, May, 2005.

Currie, Janet, and Gruber, Jonathan . "Health Insurance Eligibility, Utilization of Medical Care, and Child Health," Quarterly Journal of Economics, vol. 111, no. 2, May 1996, pp. 431-66

Currie, Janet, and Moretti, Enrico. "Biology as Destiny? Short and Long-Run Determinants of Intergenerational Transmission of Birth Weight," NBER Working Paper \#11567.

Conley, D., Strullly, K., and Neil Bennett, "A Pound of Fless or Just Proxy? Using Twin Differences To Estimate The Effect of Birth Weight on Life Chances," NBER Working Paper 9901, 2003.

Conley, D., Strullly, K., and Neil Bennett, The Starting Gate: Birth Weight and Life Chances, Berkeley, CA: University of California Press, 2003.

Goldenberg, R., and Dwight Rouse, "Prevention of Premature Birth," New England Journal of Medicine, 339, 1998.

Hanratty, M. "Canadian National Health Insurance and Infant Health," American Economic Review, 86(1), March, 1996.

Kramer, M. "Intrauterine Growth and Gestational Duration Determinants," Pediatrics, 58, 1987.

Mustard, C., Derksen, S., Berthelot, J.M., Wolfson, M. "Assessing ecologic proxies for household income: a comparison of household and neighbourhood level income measures in the study of population health status," Health and Place 5:2 (1999) 157-171. 
National Institutes of Health, "NIH Guide" Low Birth Weight in Minority Populations," PA-99-045, 1999.

Roos, LL., Walld, R., Uhanova, J. and R. Bond, "Physician visits, hospitalizations, and socioeconomic status: ambulatory care sensitive conditions in a Canadian setting," Health Services Research 40:4 (August 2005), 1167-1185.

Roos LL., and JP Nicol, "A research registry: uses, development, and accuracy," J Clin Epidemiol 52:1 (1999), 39-47.

Watson DE, Katz A, Reid RJ, Bogdanovic B, Roos N, Heppner P. Family physician workloads and access to care in Winnipeg: 1991 to 2001. Canadian Medical Association Journal. 2004;171(4):339-42. 
Table 1

Descriptive Statistics of Infant Health Measures

\begin{tabular}{|c|c|c|c|c|c|c|c|c|c|c|}
\hline \multicolumn{11}{|c|}{5 Minute APGAR Score $(0-10)$} \\
\hline \multirow[b]{2}{*}{ Sample } & \multirow[b]{2}{*}{ Mean } & \multirow[b]{2}{*}{ s.d. } & \multirow{2}{*}{$\begin{array}{c}\text { Within Family } \\
\text { s.d. }\end{array}$} & \multicolumn{7}{|c|}{ Percentile } \\
\hline & & & & $1 \mathrm{st}$ & 5th & 10th & 25th & 50th & 75th & $\mathrm{N}$ \\
\hline All Births 1979-85 & 9.094 & 0.928 & NA & 6 & 8 & 8 & 9 & 9 & 10 & 108800 \\
\hline Siblings Only & 9.131 & 0.919 & 0.646 & 6 & 8 & 8 & 9 & 9 & 10 & 54123 \\
\hline Twins Only & 8.594 & 1.397 & 0.625 & 1 & 6 & 7 & 9 & 9 & 9 & 1742 \\
\hline \multicolumn{11}{|c|}{ Birth Weight (in Grams) } \\
\hline & & & Within Family & \multicolumn{7}{|c|}{ Percentile } \\
\hline Sample & Mean & s.d. & s.d. & $1 \mathrm{st}$ & 5th & 10th & 25 th & 50th & 75th & $\mathrm{N}$ \\
\hline All Births 1979-85 & 3424.5 & 570.3 & NA & 1680 & 2500 & 2760 & 3100 & 3450 & 3780 & 109125 \\
\hline Siblings Only & 3458.3 & 556.6 & 314.1 & 1780 & 2580 & 2820 & 3140 & 3480 & 3800 & 54986 \\
\hline Twins Only & 2517.4 & 610.6 & 201.9 & 790 & 1360 & 1725 & 2181.5 & 2580 & 2930 & 1752 \\
\hline \multicolumn{11}{|c|}{ Gestation (in Weeks) } \\
\hline & & & Within Family & \multicolumn{7}{|c|}{ Percentile } \\
\hline Sample & Mean & s.d. & s.d. & $1 \mathrm{st}$ & 5th & 10th & 25th & 50th & 75th & $\mathrm{N}$ \\
\hline All Births 1979-85 & 39.4 & 2.0 & NA & 32 & 36 & 37 & 39 & 40 & 40 & 90135 \\
\hline Siblings Only & 39.4 & 1.9 & 1.1 & 33 & 37 & 38 & 39 & 40 & 40 & 45583 \\
\hline Twins Only & 36.5 & 3.3 & 0.0 & 25 & 30 & 32 & 35 & 37 & 39 & 1492 \\
\hline
\end{tabular}


Table 2

Descriptive Statistics of Outcome Measures (Sibling Sample)

1979 - 1985 Manitoba Births

\begin{tabular}{|c|c|c|c|c|}
\hline & Mean & s.d. & $\begin{array}{c}\text { Age of } \\
\text { Individual }\end{array}$ & $\mathrm{N}$ \\
\hline Infant Mortality & 0.011 & 0.105 & To 365 days & 54310 \\
\hline Death between ages 1 and 17 & 0.006 & 0.080 & 17 & 53700 \\
\hline Moved from Manitoba & 0.208 & 0.406 & 17 & 53750 \\
\hline Total Physician Visits & 14.358 & 12.610 & Age $12-17$ & 40203 \\
\hline Language Score (standardized scaled logit) & -0.016 & 1.013 & Grade 12 & 40203 \\
\hline Reached Grade 12 by Age 17 & 0.694 & 0.461 & 17 & 40203 \\
\hline Ever on Social Assistance & 0.089 & 0.285 & $\begin{array}{c}\text { Age } 18 \text { to } \\
\text { Mar-04 }\end{array}$ & 40203 \\
\hline Months on Social Assistance & 2.060 & 9.343 & $\begin{array}{l}\text { Age } 18 \text { to } \\
\text { Mar-04 }\end{array}$ & 40203 \\
\hline
\end{tabular}


Table 3

Estimated Effects of Infant Health at Birth on Infant Mortality (Death within One Year of Birth) With and Without Family Fixed Effects

\begin{tabular}{|c|c|c|c|c|c|c|c|c|c|c|}
\hline \multirow[b]{3}{*}{ APGAR $<=6$} & \multicolumn{2}{|c|}{ Full Sample } & \multicolumn{2}{|c|}{$\begin{array}{l}\text { Sibling Sample } \\
\text { No Family F.E. }\end{array}$} & \multicolumn{2}{|c|}{$\begin{array}{l}\text { Sibling Sample } \\
\text { With Family F.E. }\end{array}$} & \multicolumn{2}{|c|}{$\begin{array}{l}\text { Twins Sample } \\
\text { No Family F.E. }\end{array}$} & \multicolumn{2}{|c|}{$\begin{array}{l}\text { Twins Sample } \\
\text { With Family F.E. }\end{array}$} \\
\hline & \multicolumn{10}{|c|}{ APGAR Score (Omitted Category APGAR>6) } \\
\hline & $\begin{array}{l}0.2588 \\
(0.0021)\end{array}$ & *** & $\begin{array}{c}0.3092 \\
(0.0034)\end{array}$ & $* * *$ & $\begin{array}{c}0.3197 \\
(0.0047)\end{array}$ & $* * *$ & $\begin{array}{c}0.3123 \\
(0.0171)\end{array}$ & $* * *$ & $\begin{array}{c}0.0957 \\
(0.0237)\end{array}$ & *** \\
\hline APGAR=7-8 & $\begin{array}{l}0.0163 \\
(0.0010)\end{array}$ & $* * *$ & $\begin{array}{c}0.0189 \\
(0.0015)\end{array}$ & *** & $\begin{array}{c}0.0198 \\
(0.0022)\end{array}$ & $* * *$ & $\begin{array}{c}0.0186 \\
(0.0111)\end{array}$ & * & $\begin{array}{l}-0.0045 \\
(0.0155)\end{array}$ & \\
\hline APGAR=9 & $\begin{array}{l}0.0017 \\
(0.0006)\end{array}$ & $* * *$ & $\begin{array}{c}0.0025 \\
(0.0009)\end{array}$ & $* * *$ & $\begin{array}{c}0.0020 \\
(0.0014)\end{array}$ & & $\begin{array}{c}0.0024 \\
(0.0097)\end{array}$ & & $\begin{array}{l}-0.0014 \\
(0.0147)\end{array}$ & \\
\hline $\begin{array}{l}\text { F-test:No Inf. HIth. Effects } \\
\text { Sample Size } \\
\text { R-Squared }\end{array}$ & $\begin{array}{l}5036.06 \\
\{108893\}\end{array}$ & *** & $\begin{array}{l}2887.21 \\
\{54091\}\end{array}$ & *** & $\begin{array}{l}1588.14 \\
\{54091\}\end{array}$ & $* * *$ & $\begin{array}{l}137.49 \\
\{1740\}\end{array}$ & *** & $\begin{array}{c}8.93 \\
\{1740\}\end{array}$ & *** \\
\hline \multirow[t]{2}{*}{ R-Squared } & 0.12 & & 0.13 & & 0.50 & & 0.34 & & 0.84 & \\
\hline & \multicolumn{10}{|c|}{ Birth Weight (Omitted Category BW $=2500-3000$ grams) } \\
\hline BW $<1000$ & $\begin{array}{l}0.8120 \\
(0.0046)\end{array}$ & $* * *$ & $\begin{array}{c}0.8572 \\
(0.0071)\end{array}$ & $* * *$ & $\begin{array}{c}0.8723 \\
(0.0099)\end{array}$ & $* * *$ & $\begin{array}{c}0.7249 \\
(0.0292)\end{array}$ & $* * *$ & $\begin{array}{c}0.2532 \\
(0.0701)\end{array}$ & *** \\
\hline BW 1000-1500 & $\begin{array}{l}0.2657 \\
(0.0039)\end{array}$ & $* * *$ & $\begin{array}{c}0.3622 \\
(0.0066)\end{array}$ & $* * *$ & $\begin{array}{c}0.3912 \\
(0.0093)\end{array}$ & $* * *$ & $\begin{array}{c}0.2099 \\
(0.0220)\end{array}$ & $* * *$ & $\begin{array}{l}0.0848 \\
(0.0384)\end{array}$ & ** \\
\hline BW $1500-2500$ & $\begin{array}{c}0.0320 \\
(0.0013)\end{array}$ & $* * *$ & $\begin{array}{c}0.0479 \\
(0.0022)\end{array}$ & $* * *$ & $\begin{array}{c}0.0630 \\
(0.0034)\end{array}$ & $* * *$ & $\begin{array}{c}0.0051 \\
(0.0174)\end{array}$ & & $\begin{array}{l}0.0048 \\
(0.0246)\end{array}$ & \\
\hline BW 2500-3000 & $\begin{array}{l}0.0058 \\
(0.0008)\end{array}$ & $* * *$ & $\begin{array}{c}0.0065 \\
(0.0012)\end{array}$ & $* \star *$ & $\begin{array}{l}0.0130 \\
(0.0021)\end{array}$ & $* \star *$ & $\begin{array}{c}0.0063 \\
(0.0174)\end{array}$ & & $\begin{array}{l}-0.0043 \\
(0.0231)\end{array}$ & \\
\hline BW 3000-3500 & $\begin{array}{c}0.0015 \\
(0.0006)\end{array}$ & $* \star *$ & $\begin{array}{c}0.0018 \\
(0.0009)\end{array}$ & ** & $\begin{array}{c}0.0042 \\
(0.0014)\end{array}$ & $* * *$ & $\begin{array}{l}-0.0006 \\
(0.0182)\end{array}$ & & $\begin{array}{l}-0.0017 \\
(0.0218)\end{array}$ & \\
\hline \multirow[t]{2}{*}{$\begin{array}{l}\text { F-test:No Inf. Hlth. Effects } \\
\text { Sample Size } \\
\text { R-Squared }\end{array}$} & $\begin{array}{c}7099.73 \\
\{109114\} \\
0.05\end{array}$ & $* * *$ & $\begin{array}{c}3586.36 \\
\{54986\} \\
0.06\end{array}$ & $* * *$ & $\begin{array}{c}1899.91 \\
\{54986\} \\
0.49\end{array}$ & $* \star \star$ & $\begin{array}{c}213.85 \\
\{2020\} \\
0.24\end{array}$ & *** & $\begin{array}{c}3.25 \\
\{2020\} \\
0.86\end{array}$ & *** \\
\hline & \multicolumn{10}{|c|}{ Gestation (Omitted Category 40-41 Weeks) } \\
\hline Gestation $<=36$ weeks & $\begin{array}{l}0.0837 \\
(0.0014)\end{array}$ & $* \star *$ & $\begin{array}{c}0.1060 \\
(0.0023)\end{array}$ & $* * *$ & $\begin{array}{c}0.1187 \\
(0.0039)\end{array}$ & $* \star \star$ & $\begin{array}{c}0.0804 \\
(0.0104)\end{array}$ & *** & NA & \\
\hline Gestation 37 weeks & $\begin{array}{l}0.0056 \\
(0.0016)\end{array}$ & $* * *$ & $\begin{array}{c}0.0084 \\
(0.0025)\end{array}$ & $* * *$ & $\begin{array}{c}0.0142 \\
(0.0041)\end{array}$ & $* \star *$ & $\begin{array}{c}0.0060 \\
(0.0141)\end{array}$ & & NA & \\
\hline Gestation 38 weeks & $\begin{array}{l}0.0035 \\
(0.0010)\end{array}$ & $* \star *$ & $\begin{array}{c}0.0052 \\
(0.0015)\end{array}$ & $* * *$ & $\begin{array}{c}0.0073 \\
(0.0026)\end{array}$ & $* * *$ & $\begin{array}{c}0.0044 \\
(0.0123)\end{array}$ & & NA & \\
\hline Gestation 39 weeks & $\begin{array}{l}0.0010 \\
(0.0008)\end{array}$ & & $\begin{array}{c}0.0005 \\
(0.0013)\end{array}$ & & $\begin{array}{l}-0.0003 \\
(0.0021)\end{array}$ & & $\begin{array}{c}0.0089 \\
(0.0132)\end{array}$ & & NA & \\
\hline Gestation $>=42$ weeks & $\begin{array}{l}0.0005 \\
(0.0013)\end{array}$ & & $\begin{array}{l}-0.0003 \\
(0.0019)\end{array}$ & & $\begin{array}{l}0.0005 \\
(0.0031)\end{array}$ & & $\begin{array}{c}0.0001 \\
(0.0237)\end{array}$ & & NA & \\
\hline $\begin{array}{l}\text { F-test:No Inf. Hlth. Effects } \\
\text { Sample Size }\end{array}$ & $\begin{array}{l}722.48 \\
\{90460\}\end{array}$ & $* * *$ & $\begin{array}{c}435.15 \\
\{46183\}\end{array}$ & $* * *$ & $\begin{array}{r}198.70 \\
\{46183\}\end{array}$ & $* * *$ & $\begin{array}{c}7.55 \\
\{1976\}\end{array}$ & *** & NA & \\
\hline R-Squared & 0.09 & & 0.10 & & 0.55 & & 0.29 & & NA & \\
\hline
\end{tabular}

All regression models include additional fixed effects for mother's martial status, gender of child, and family sibling size dummies for the birth order of the child within each family size. One, two, and three asteriks indicate statistical significance at the 10,5, and 1 percent levels respectively. 
Table 4

Estimated Effects of Infant Health at Birth on Mortality between Ages 1 to 17 With and Without Family Fixed Effects

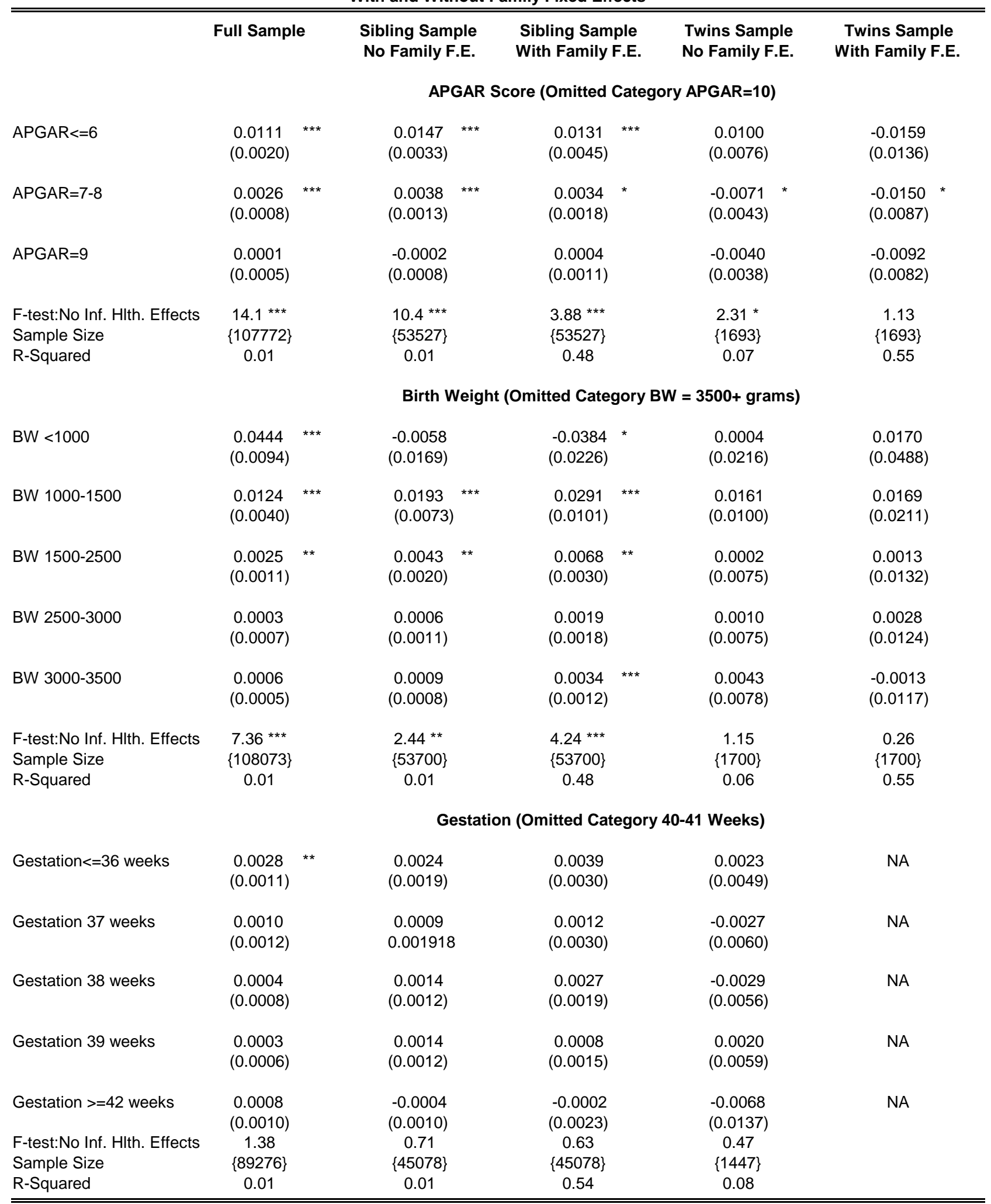

All regression models include additional fixed effects for mother's martial status, gender of child, and family sibling size dummies for the birth order of the child within each family size. One, two, and three asteriks indicate statistical significance at the 10,5 , and 1 percent levels respectively. 
Table 5

Estimated Effects of Infant Health at Birth on Mobility out of Manitoba Before Age 18 With and Without Family Fixed Effects

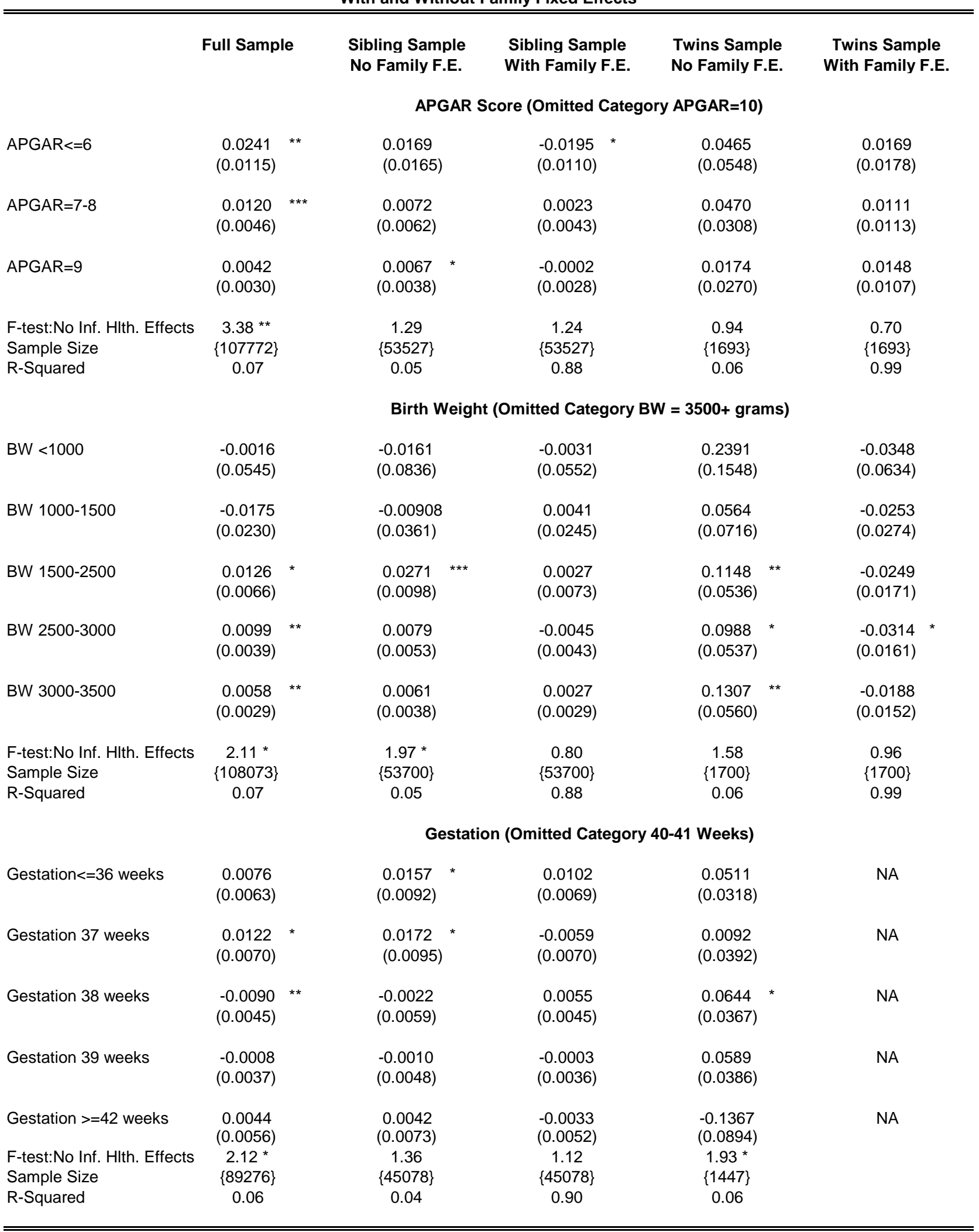

All regression models include additional fixed effects for mother's martial status, gender of child, and family sibling size dummies for the birth order of the child within each family size. One, two, and three asteriks indicate statistical significance at the 10, 5, and 1 percent levels respectively. 
Table 6

Estimated Effects of Infant Health at Birth on Total Physician Visits Between Ages 12 and 17

With and Without Family Fixed Effects

\begin{tabular}{|c|c|c|c|c|c|c|c|c|c|c|}
\hline \multirow[b]{3}{*}{ APGAR<=6 } & \multicolumn{2}{|c|}{ Full Sample } & \multicolumn{2}{|c|}{$\begin{array}{l}\text { Sibling Sample } \\
\text { No Family F.E. }\end{array}$} & \multicolumn{2}{|c|}{$\begin{array}{l}\text { Sibling Sample } \\
\text { Family F.E. }\end{array}$} & \multicolumn{2}{|c|}{$\begin{array}{l}\text { Twins Sample } \\
\text { No Family F.E. }\end{array}$} & \multicolumn{2}{|l|}{$\begin{array}{l}\text { Twins Sample } \\
\text { Family F.E. }\end{array}$} \\
\hline & \multicolumn{10}{|c|}{ APGAR Score (Omitted Category APGAR=10) } \\
\hline & $\begin{array}{c}1.9767 \\
(0.4213)\end{array}$ & $* * *$ & $\begin{array}{l}1.5734 \\
(0.6186)\end{array}$ & ** & $\begin{array}{l}1.5356 \\
(0.6768)\end{array}$ & ** & $\begin{array}{c}1.9612 \\
(1.7188)\end{array}$ & & $\begin{array}{c}0.7656 \\
(2.2051)\end{array}$ & \\
\hline APGAR=7-8 & $\begin{array}{c}0.5790 \\
(0.1629)\end{array}$ & $* * *$ & $\begin{array}{c}0.2692 \\
(0.2243)\end{array}$ & & $\begin{array}{l}-0.5566 \\
(0.2561)\end{array}$ & ** & $\begin{array}{l}-1.0923 \\
(0.9297)\end{array}$ & & $\begin{array}{l}-1.2239 \\
(1.3159)\end{array}$ & \\
\hline APGAR=9 & $\begin{array}{c}0.3954 \\
(0.1043)\end{array}$ & $* * *$ & $\begin{array}{l}0.3173 \\
(0.1376)\end{array}$ & ** & $\begin{array}{l}-0.1826 \\
(0.1628)\end{array}$ & & $\begin{array}{c}0.0717 \\
(0.8024)\end{array}$ & & $\begin{array}{l}-0.4005 \\
(1.2520)\end{array}$ & \\
\hline $\begin{array}{l}\text { F-test:No Inf. Hlth. Effects } \\
\text { Sample Size } \\
\text { R-Squared }\end{array}$ & $\begin{array}{c}11.76 \\
\{79143\} \\
0.04\end{array}$ & $* * *$ & $\begin{array}{c}3.47 \\
\{40078\} \\
0.05\end{array}$ & ** & $\begin{array}{c}3.81 \\
\{40078\} \\
0.68\end{array}$ & *** & $\begin{array}{c}1.58 \\
\{1348\} \\
0.09\end{array}$ & & $\begin{array}{c}0.74 \\
\{1348\} \\
0.78\end{array}$ & \\
\hline R-Squared & \multicolumn{10}{|c|}{ Birth Weight (Omitted Category BW $=3500+$ grams) } \\
\hline$B W<1000$ & $\begin{array}{l}-0.9530 \\
(1.9892)\end{array}$ & & $\begin{array}{l}-0.8204 \\
(3.1370)\end{array}$ & & $\begin{array}{l}2.2148 \\
(3.2498)\end{array}$ & & $\begin{array}{c}2.6851 \\
(4.8230)\end{array}$ & & $\begin{array}{c}4.9343 \\
(10.6648)\end{array}$ & \\
\hline BW 1000-1500 & $\begin{array}{c}1.0137 \\
(0.8185)\end{array}$ & & $\begin{array}{l}-0.5904 \\
(1.3344)\end{array}$ & & $\begin{array}{l}-1.6869 \\
(1.4809)\end{array}$ & & $\begin{array}{c}9.3137 \\
(2.1409)\end{array}$ & *** & $\begin{array}{c}7.3252 \\
(2.9635)\end{array}$ & ** \\
\hline BW 1500-2500 & $\begin{array}{c}0.4262 \\
(0.2359)\end{array}$ & * & $\begin{array}{l}-0.1540 \\
(0.3662)\end{array}$ & & $\begin{array}{l}0.5461 \\
(0.4425)\end{array}$ & & $\begin{array}{c}3.3341 \\
(1.5216)\end{array}$ & ** & $\begin{array}{c}0.1926 \\
(1.8861)\end{array}$ & \\
\hline BW 2500-3000 & $\begin{array}{c}0.2481 \\
(0.1402)\end{array}$ & * & $\begin{array}{c}0.3470 \\
(0.1941)\end{array}$ & * & $\begin{array}{l}0.2464 \\
(0.2537)\end{array}$ & & $\begin{array}{c}3.5727 \\
(1.5280)\end{array}$ & ** & $\begin{array}{c}0.1849 \\
(1.7688)\end{array}$ & \\
\hline BW $3000-3500$ & $\begin{array}{c}0.2125 \\
(0.1027)\end{array}$ & $* *$ & $\begin{array}{c}0.3026 \\
(0.1375)\end{array}$ & ** & $\begin{array}{l}0.3215 \\
(0.1704)\end{array}$ & * & $\begin{array}{c}2.9624 \\
(1.6084)\end{array}$ & * & $\begin{array}{c}1.9898 \\
(1.6555)\end{array}$ & \\
\hline $\begin{array}{l}\text { F-test:No Inf. Hith. Effects } \\
\text { Sample Size } \\
\text { R-Squared }\end{array}$ & $\begin{array}{c}1.78 \\
\{79363\} \\
0.04\end{array}$ & & $\begin{array}{c}1.47 \\
\{40203\} \\
0.05\end{array}$ & & $\begin{array}{c}1.25 \\
\{40203\} \\
0.68\end{array}$ & & $\begin{array}{c}4.03 \\
\{1354\} \\
0.10\end{array}$ & *** & $\begin{array}{c}2.77 \\
\{1354\} \\
0.78\end{array}$ & ** \\
\hline R-Squared & \multicolumn{10}{|c|}{ Gestation (Omitted Category 40-41 Weeks) } \\
\hline Gestation $<=36$ weeks & $\begin{array}{c}0.2814 \\
(0.2271)\end{array}$ & & $\begin{array}{l}-0.2208 \\
(0.3395)\end{array}$ & & $\begin{array}{l}-0.5687 \\
(0.4291)\end{array}$ & & $\begin{array}{c}0.8215 \\
(0.9276)\end{array}$ & & NA & \\
\hline Gestation 37 weeks & $\begin{array}{c}0.3913 \\
(0.2491)\end{array}$ & & $\begin{array}{c}0.1131 \\
(0.3487)\end{array}$ & & $\begin{array}{l}-0.1167 \\
(0.4345)\end{array}$ & & $\begin{array}{c}3.1315 \\
(1.1326)\end{array}$ & *** & NA & \\
\hline Gestation 38 weeks & $\begin{array}{c}0.4832 \\
(0.1582)\end{array}$ & $* \star *$ & $\begin{array}{c}0.2030 \\
(0.2119)\end{array}$ & & $\begin{array}{l}0.0325 \\
(0.2693)\end{array}$ & & $\begin{array}{r}-0.1308 \\
(1.0700)\end{array}$ & & NA & \\
\hline Gestation 39 weeks & $\begin{array}{c}0.0867 \\
(0.1305)\end{array}$ & & $\begin{array}{l}-0.1401 \\
(0.1731)\end{array}$ & & $\begin{array}{l}-0.1719 \\
(0.2151)\end{array}$ & & $\begin{array}{l}-0.0701 \\
(1.1335)\end{array}$ & & NA & \\
\hline Gestation $>=42$ weeks & $\begin{array}{c}0.0874 \\
(0.1973)\end{array}$ & & $\begin{array}{l}-0.0581 \\
(0.2636)\end{array}$ & & $\begin{array}{l}-0.0985 \\
(0.3201)\end{array}$ & & $\begin{array}{l}-1.3445 \\
(2.3796)\end{array}$ & & NA & \\
\hline $\begin{array}{l}\text { F-test:No Inf. Hlth. Effects } \\
\text { Sample Size }\end{array}$ & $\begin{array}{c}2.29 \\
\{66504\}\end{array}$ & $\star \star$ & $\begin{array}{c}0.53 \\
\{33921\}\end{array}$ & & $\begin{array}{c}0.48 \\
\{33921\}\end{array}$ & & $\begin{array}{c}2.59 \\
\{1166\}\end{array}$ & ** & NA & \\
\hline R-Squared & 0.04 & & 0.05 & & 0.72 & & 0.10 & & NA & \\
\hline
\end{tabular}

All regression models include additional fixed effects for mother's martial status, gender of child, and family sibling size dummies for the birth order of the child within each family size. One, two, and three asteriks indicate statistical significance at the 10, 5, and 1 percent levels respectively. 
Table 7

Estimated Effects of Infant Health at Birth on Language Arts Score With and Without Family Fixed Effects

\begin{tabular}{|c|c|c|c|c|c|c|c|c|c|}
\hline \multirow[b]{3}{*}{ APGAR<=6 } & \multicolumn{2}{|c|}{ Full Sample } & \multicolumn{2}{|c|}{$\begin{array}{l}\text { Sibling Sample } \\
\text { No Family F.E. }\end{array}$} & \multicolumn{2}{|c|}{$\begin{array}{l}\text { Sibling Sample } \\
\text { Family F.E. }\end{array}$} & $\begin{array}{l}\text { Twins Sample } \\
\text { No Family F.E. }\end{array}$ & \multicolumn{2}{|l|}{$\begin{array}{c}\text { Twins Sample } \\
\text { Family F.E. }\end{array}$} \\
\hline & \multicolumn{9}{|c|}{ APGAR Score (Omitted Category APGAR>6) } \\
\hline & $\begin{array}{l}-0.1541 \\
(0.0297)\end{array}$ & $* * *$ & $\begin{array}{l}-0.1730 \\
(0.0450)\end{array}$ & $\star \star \star *$ & $\begin{array}{l}-0.0913 \\
(0.0481)\end{array}$ & * & $\begin{array}{c}0.1254 \\
(0.1457)\end{array}$ & $\begin{array}{c}0.0756 \\
(0.1568)\end{array}$ & \\
\hline APGAR=7-8 & $\begin{array}{l}-0.0503 \\
(0.0116)\end{array}$ & $* * *$ & $\begin{array}{l}-0.0436 \\
(0.0164)\end{array}$ & $\star \star \star$ & $\begin{array}{l}-0.0245 \\
(0.0183)\end{array}$ & & $\begin{array}{c}0.0326 \\
(0.0786)\end{array}$ & $\begin{array}{l}-0.1021 \\
(0.0936)\end{array}$ & \\
\hline $\mathrm{APGAR}=9$ & $\begin{array}{c}0.0069 \\
(0.0074)\end{array}$ & & $\begin{array}{c}0.0184 \\
(0.0101)\end{array}$ & * & $\begin{array}{l}-0.0012 \\
(0.0116)\end{array}$ & & $\begin{array}{c}0.0444 \\
(0.0676)\end{array}$ & $\begin{array}{l}-0.0952 \\
(0.0890)\end{array}$ & \\
\hline $\begin{array}{l}\text { F-test:No Inf. Hith. Effects } \\
\text { Sample Size } \\
\text { R-Squared }\end{array}$ & $\begin{array}{c}18.52 \\
\{79194\} \\
0.17\end{array}$ & $\star \star \star *$ & $\begin{array}{c}10.97 \\
\{40514\} \\
0.20\end{array}$ & $\star \star \star *$ & $\begin{array}{c}1.82 \\
\{40514\} \\
0.75\end{array}$ & & $\begin{array}{c}0.30 \\
\{1364\} \\
0.20\end{array}$ & $\begin{array}{c}0.99 \\
\{1364\} \\
0.87\end{array}$ & \\
\hline & \multicolumn{9}{|c|}{ Birth Weight (Omitted Category BW = 2500-3000 grams) } \\
\hline $\mathrm{BW}<1000$ & $\begin{array}{l}-0.31424 \\
0.141101\end{array}$ & $* *$ & \multicolumn{2}{|l|}{$\begin{array}{l}-0.25756 \\
0.230887\end{array}$} & \multicolumn{2}{|l|}{$\begin{array}{l}-0.04906 \\
0.231668\end{array}$} & $\begin{array}{l}-0.54153 \\
0.408117\end{array}$ & \multicolumn{2}{|l|}{$\begin{array}{r}0.01819 \\
0.761597\end{array}$} \\
\hline BW 1000-1500 & $\begin{array}{l}-0.26002 \\
0.058061\end{array}$ & $* \star *$ & \multicolumn{2}{|c|}{$\begin{array}{c}-0.2302^{* *} \\
0.098216\end{array}$} & \multicolumn{2}{|l|}{$\begin{array}{l}-0.08117 \\
0.105565\end{array}$} & $\begin{array}{l}-0.46083^{* *} \\
0.181157\end{array}$ & \multicolumn{2}{|l|}{$\begin{array}{l}-0.18498 \\
0.211632\end{array}$} \\
\hline BW 1500-2500 & $\begin{array}{r}-0.1519 \\
0.016731\end{array}$ & $* * *$ & \multicolumn{2}{|c|}{$\begin{array}{l}-0.21882^{* * *} \\
0.026951\end{array}$} & \multicolumn{2}{|l|}{$\begin{array}{l}-0.04925 \\
0.031547\end{array}$} & $\begin{array}{l}-0.18261 \\
0.128753\end{array}$ & \multicolumn{2}{|l|}{$\begin{array}{l}-0.09871 \\
0.134692\end{array}$} \\
\hline BW 2500-3000 & $\begin{array}{l}-0.1172 \\
(0.0099)\end{array}$ & $\star \star \star *$ & $\begin{array}{l}-0.1303 \\
(0.0143)\end{array}$ & $\star \star \star$ & $\begin{array}{l}-0.0477 \\
(0.0181)\end{array}$ & ** & $\begin{array}{l}-0.2063 \\
(0.1293)\end{array}$ & $\begin{array}{l}-0.2139 \\
(0.1263)\end{array}$ & \\
\hline BW 3000-3500 & $\begin{array}{l}-0.0339 \\
(0.0073)\end{array}$ & $\star \star \star *$ & $\begin{array}{l}-0.0459 \\
(0.0101)\end{array}$ & $\star \star \star$ & $\begin{array}{l}-0.0154 \\
(0.0121)\end{array}$ & & $\begin{array}{l}-0.0969 \\
(0.1361)\end{array}$ & $\begin{array}{l}-0.0672 \\
(0.1182)\end{array}$ & \\
\hline $\begin{array}{l}\text { F-test:No Inf. Hlth. Effects } \\
\text { Sample Size }\end{array}$ & $\begin{array}{c}42.74 \\
\{79363\}\end{array}$ & $\star * *$ & $\begin{array}{c}27.73 \\
\{40203\}\end{array}$ & 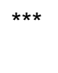 & $\begin{array}{c}1.57 \\
\{40203\}\end{array}$ & & $\begin{array}{c}1.95 \\
\{1354\}\end{array}$ * & $\begin{array}{c}1.54 \\
\{1354\}\end{array}$ & \\
\hline \multirow[t]{2}{*}{ R-Squared } & 0.17 & & 0.20 & & 0.74 & & 0.21 & 0.86 & \\
\hline & \multicolumn{9}{|c|}{ Gestation (Omitted Category 40-41 Weeks) } \\
\hline Gestation<=36 weeks & $\begin{array}{l}-0.0797 \\
(0.0161)\end{array}$ & $\star * *$ & $\begin{array}{l}-0.1232 \\
(0.0251)\end{array}$ & $\star \star \star$ & $\begin{array}{c}0.0255 \\
(0.0303)\end{array}$ & & $\begin{array}{c}0.0061 \\
(0.0800)\end{array}$ & NA & \\
\hline Gestation 37 weeks & $\begin{array}{l}-0.0678 \\
(0.0177)\end{array}$ & $\star \star \star$ & $\begin{array}{l}-0.0999 \\
(0.0258)\end{array}$ & $\star * *$ & $\begin{array}{l}-0.0076 \\
(0.0307)\end{array}$ & & $\begin{array}{c}0.1317 \\
(0.0976)\end{array}$ & NA & \\
\hline Gestation 38 weeks & $\begin{array}{l}-0.0114 \\
(0.0112)\end{array}$ & & $\begin{array}{l}-0.0166 \\
(0.0157)\end{array}$ & & $\begin{array}{c}0.0263 \\
(0.0190)\end{array}$ & & $\begin{array}{l}-0.0708 \\
(0.0922)\end{array}$ & NA & \\
\hline Gestation 39 weeks & $\begin{array}{c}0.0083 \\
(0.0093)\end{array}$ & & $\begin{array}{c}0.0003 \\
(0.0128)\end{array}$ & & $\begin{array}{c}0.0037 \\
(0.0152)\end{array}$ & & $\begin{array}{c}0.0543 \\
(0.0977)\end{array}$ & NA & \\
\hline Gestation >=42 weeks & $\begin{array}{l}-0.0204 \\
(0.0140)\end{array}$ & & $\begin{array}{l}-0.0231 \\
(0.0195)\end{array}$ & & $\begin{array}{l}-0.0089 \\
(0.0226)\end{array}$ & & $\begin{array}{l}-0.1789 \\
(0.2051)\end{array}$ & NA & \\
\hline $\begin{array}{l}\text { F-test:No Inf. Hlth. Effects } \\
\text { Sample Size }\end{array}$ & $\begin{array}{c}8.44 \\
\{66504\}\end{array}$ & $\star * \star$ & $\begin{array}{c}7.70 \\
\{33921\}\end{array}$ & $\star \star \star ~$ & $\begin{array}{c}0.60 \\
\{33921\}\end{array}$ & & $\begin{array}{c}1.28 \\
\{1166\}\end{array}$ & NA & \\
\hline R-Squared & 0.17 & & 0.20 & & 0.79 & & 0.21 & NA & \\
\hline
\end{tabular}

All regression models include additional fixed effects for mother's martial status, gender of child, and family sibling size dummies for the birth order of the child within each family size. One, two, and three asteriks indicate statistical significance at the 10,5 , and 1 percent levels respectively. 
Table 8

Estimated Effects of Infant Health at Birth on Reaching Grade 12 by Age 17 With and Without Family Fixed Effects

\begin{tabular}{|c|c|c|c|c|c|c|c|c|c|c|}
\hline \multirow[b]{3}{*}{ APGAR< $<=6$} & \multicolumn{2}{|c|}{ Full Sample } & \multicolumn{2}{|c|}{$\begin{array}{l}\text { Sibling Sample } \\
\text { No Family F.E. }\end{array}$} & \multicolumn{2}{|c|}{$\begin{array}{l}\text { Sibling Sample } \\
\text { Family F.E. }\end{array}$} & \multicolumn{2}{|c|}{$\begin{array}{l}\text { Twins Sample } \\
\text { No Family F.E. }\end{array}$} & \multicolumn{2}{|c|}{$\begin{array}{c}\text { Twins Sample } \\
\text { Family F.E. }\end{array}$} \\
\hline & \multicolumn{10}{|c|}{ APGAR Score (Omitted Category APGAR>6) } \\
\hline & $\begin{array}{l}-0.0697 \\
(0.0137)\end{array}$ & $\star \star * *$ & $\begin{array}{l}-0.0739 \\
(0.0206)\end{array}$ & $* \star \star$ & $\begin{array}{l}-0.0410 \\
(0.0239)\end{array}$ & * & $\begin{array}{c}0.0710 \\
(0.0701)\end{array}$ & & $\begin{array}{c}0.0317 \\
(0.0706)\end{array}$ & \\
\hline APGAR=7-8 & $\begin{array}{l}-0.0240 \\
(0.0053)\end{array}$ & $* * *$ & $\begin{array}{l}-0.0302 \\
(0.0075)\end{array}$ & $* \star *$ & $\begin{array}{l}-0.0203 \\
(0.0091)\end{array}$ & ** & $\begin{array}{c}0.0179 \\
(0.0378)\end{array}$ & & $\begin{array}{l}-0.0210 \\
(0.0421)\end{array}$ & \\
\hline APGAR=9 & $\begin{array}{c}0.0058 \\
(0.0034)\end{array}$ & * & $\begin{array}{c}0.0111 \\
(0.0046)\end{array}$ & ** & $\begin{array}{c}0.0051 \\
(0.0058)\end{array}$ & & $\begin{array}{c}0.0428 \\
(0.0325)\end{array}$ & & $\begin{array}{l}-0.0156 \\
(0.0401)\end{array}$ & \\
\hline $\begin{array}{l}\text { F-test:No Inf. Hlth. Effects } \\
\text { Sample Size } \\
\text { R-Squared }\end{array}$ & $\begin{array}{c}21.3 \\
\{79194\} \\
0.15\end{array}$ & $* \star *$ & $\begin{array}{c}16.3 \\
\{40514\} \\
0.18\end{array}$ & $* * *$ & $\begin{array}{c}4.12 \\
\{40514\} \\
0.70\end{array}$ & $* * *$ & $\begin{array}{c}0.81 \\
\{1364\} \\
0.18\end{array}$ & & $\begin{array}{c}0.32 \\
\{1364\} \\
0.88\end{array}$ & \\
\hline R-Squared & \multicolumn{10}{|c|}{ Birth Weight (Omitted Category BW = 2500-3000 grams) } \\
\hline$B W<1000$ & $\begin{array}{l}-0.1842 \\
(0.0649)\end{array}$ & $* * *$ & $\begin{array}{l}-0.1308 \\
(0.1060)\end{array}$ & & $\begin{array}{c}0.0546 \\
(0.1153)\end{array}$ & & $\begin{array}{l}-0.3346 \\
(0.1968)\end{array}$ & * & $\begin{array}{l}-0.0837 \\
(0.3434)\end{array}$ & \\
\hline BW 1000-1500 & $\begin{array}{l}-0.1353 \\
(0.0267)\end{array}$ & *** & $\begin{array}{l}-0.1271 \\
(0.0451)\end{array}$ & $\star \star \star ~$ & $\begin{array}{l}-0.1410 \\
(0.0525)\end{array}$ & $* * *$ & $\begin{array}{l}-0.2708 \\
(0.0874)\end{array}$ & 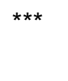 & $\begin{array}{l}-0.2315 \\
(0.0954)\end{array}$ & ** \\
\hline BW 1500-2500 & $\begin{array}{l}-0.0793 \\
(0.0077)\end{array}$ & $\star \star \star ~$ & $\begin{array}{l}-0.1168 \\
(0.0124)\end{array}$ & $* * *$ & $\begin{array}{l}-0.0815 \\
(0.0157)\end{array}$ & $\star \star \star *$ & $\begin{array}{l}-0.1284 \\
(0.0621)\end{array}$ & ** & $\begin{array}{l}-0.0685 \\
(0.0607)\end{array}$ & \\
\hline BW 2500-3000 & $\begin{array}{l}-0.0398 \\
(0.0046)\end{array}$ & $\star \star \star *$ & $\begin{array}{l}-0.0496 \\
(0.0066)\end{array}$ & $\star \star \star *$ & $\begin{array}{l}-0.0430 \\
(0.0090)\end{array}$ & $* \star *$ & $\begin{array}{l}-0.1094 \\
(0.0624)\end{array}$ & * & $\begin{array}{l}-0.0921 \\
(0.0570)\end{array}$ & \\
\hline BW 3000-3500 & $\begin{array}{l}-0.0125 \\
(0.0034)\end{array}$ & $\star \star \star *$ & $\begin{array}{l}-0.0189 \\
(0.0046)\end{array}$ & $\star * \star$ & $\begin{array}{l}-0.0243 \\
(0.0060)\end{array}$ & ** & $\begin{array}{l}-0.0639 \\
(0.0656)\end{array}$ & & $\begin{array}{l}-0.0488 \\
(0.0533)\end{array}$ & \\
\hline $\begin{array}{l}\text { F-test:No Inf. Hlth. Effects } \\
\text { Sample Size }\end{array}$ & $\begin{array}{c}37.47 \\
\{79363\}\end{array}$ & $* \star *$ & $\begin{array}{c}27.74 \\
\{40203\}\end{array}$ & $* * *$ & $\begin{array}{c}8.98 \\
\{40203\}\end{array}$ & $* \star *$ & $\begin{array}{c}2.91 \\
\{1354\}\end{array}$ & ** & $\begin{array}{c}1.72 \\
\{1354\}\end{array}$ & \\
\hline \multirow[t]{2}{*}{ R-Squared } & 0.16 & & 0.18 & & 0.69 & & 0.19 & & 0.88 & \\
\hline & \multicolumn{10}{|c|}{ Gestation (Omitted Category 40-41 Weeks) } \\
\hline Gestation $<=36$ weeks & $\begin{array}{l}-0.0602 \\
(0.0074)\end{array}$ & $\star \star \star *$ & $\begin{array}{l}-0.0843 \\
(0.0115)\end{array}$ & $\star \star \star *$ & $\begin{array}{l}-0.0403 \\
(0.0150)\end{array}$ & $* * *$ & $\begin{array}{l}-0.0498 \\
(0.0387)\end{array}$ & & NA & \\
\hline Gestation 37 weeks & $\begin{array}{l}-0.0246 \\
(0.0081)\end{array}$ & $* \star *$ & $\begin{array}{l}-0.0426 \\
(0.0118)\end{array}$ & $* \star *$ & $\begin{array}{l}-0.0345 \\
(0.0152)\end{array}$ & ** & $\begin{array}{c}0.0473 \\
(0.0472)\end{array}$ & & NA & \\
\hline Gestation 38 weeks & $\begin{array}{l}-0.0064 \\
(0.0051)\end{array}$ & & $\begin{array}{l}-0.0139 \\
(0.0072)\end{array}$ & * & $\begin{array}{l}-0.0252 \\
(0.0094)\end{array}$ & $* \star \star$ & $\begin{array}{c}0.0419 \\
(0.0446)\end{array}$ & & NA & \\
\hline Gestation 39 weeks & $\begin{array}{c}0.0076 \\
(0.0042)\end{array}$ & * & $\begin{array}{l}0.0062 \\
(0.0059)\end{array}$ & & $\begin{array}{l}-0.0014 \\
(0.0075)\end{array}$ & & $\begin{array}{l}0.0580 \\
(0.0473)\end{array}$ & & NA & \\
\hline Gestation >=42 weeks & $\begin{array}{l}-0.0067 \\
(0.0064)\end{array}$ & & $\begin{array}{l}-0.0099 \\
(0.0089)\end{array}$ & & $\begin{array}{l}-0.0116 \\
(0.0112)\end{array}$ & & $\begin{array}{l}-0.1740 \\
(0.0992)\end{array}$ & * & NA & \\
\hline $\begin{array}{l}\text { F-test:No Inf. Hlth. Effects } \\
\text { Sample Size }\end{array}$ & $\begin{array}{c}17.14 \\
\{66504\}\end{array}$ & $\star \star \star *$ & $\begin{array}{c}14.37 \\
\{33921\}\end{array}$ & $* * *$ & $\begin{array}{c}3.19 \\
\{33921\}\end{array}$ & 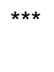 & $\begin{array}{c}3.23 \\
\{1166\}\end{array}$ & 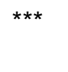 & NA & \\
\hline R-Squared & 0.16 & & 0.19 & & 0.75 & & 0.19 & & NA & \\
\hline
\end{tabular}

All regression models include additional fixed effects for mother's martial status, gender of child, and family sibling size dummies for the birth order of the child within each family size. One, two, and three asteriks indicate statistical significance at the 10,5 , and 1 percent levels respectively. 
Table 9

Estimated Effects of Infant Health at Birth on Social Assistance Take-up With and Without Family Fixed Effects

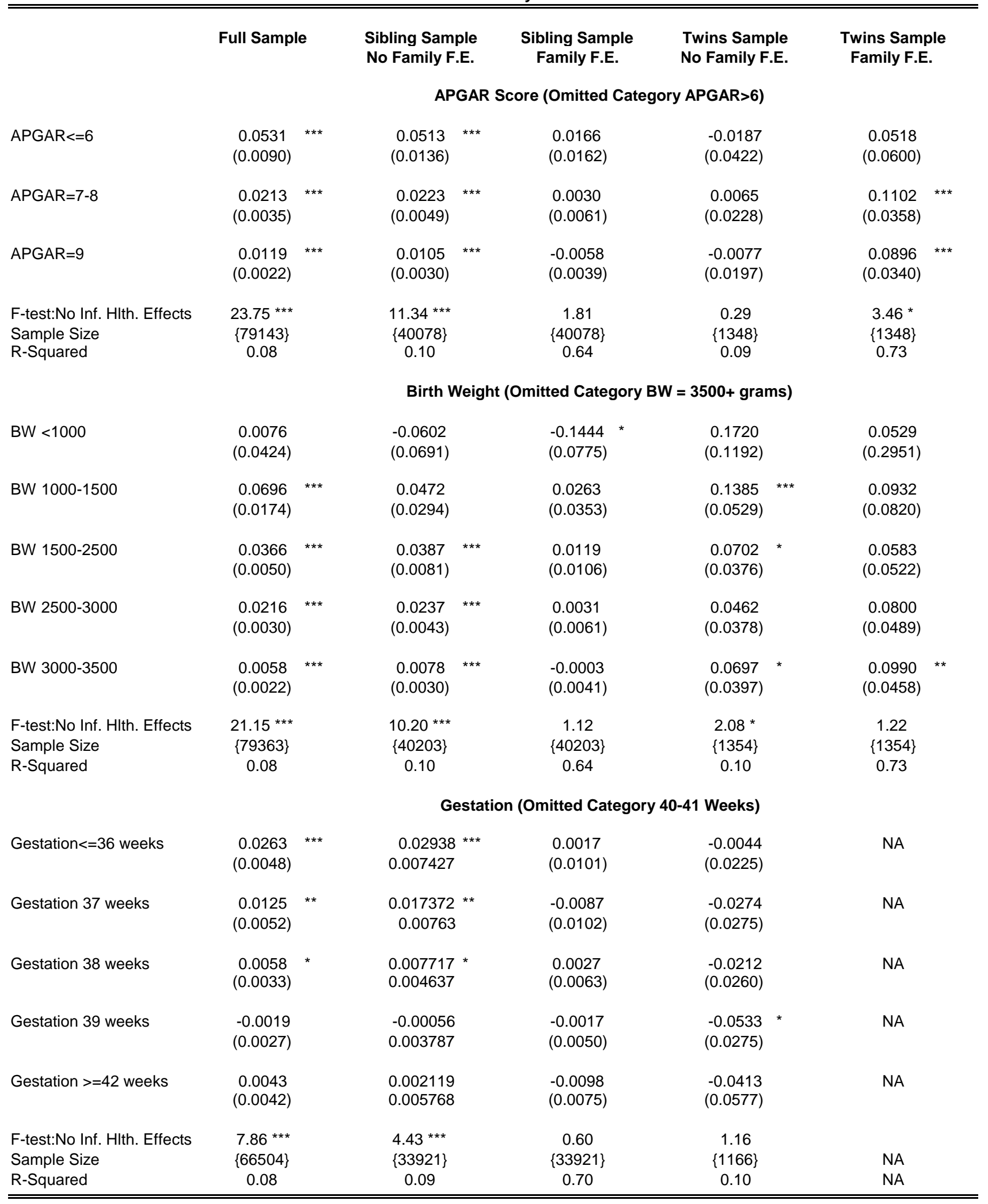

All regression models include additional fixed effects for mother's martial status, gender of child, and family sibling size dummies for the birth order of the child within each family size. One, two, and three asteriks indicate statistical significance at the 10,5 , and 1 percent levels respectively. 
Table 10

Estimated Effects of Infant Health at Birth on Months on Social Assistance With and Without Family Fixed Effects

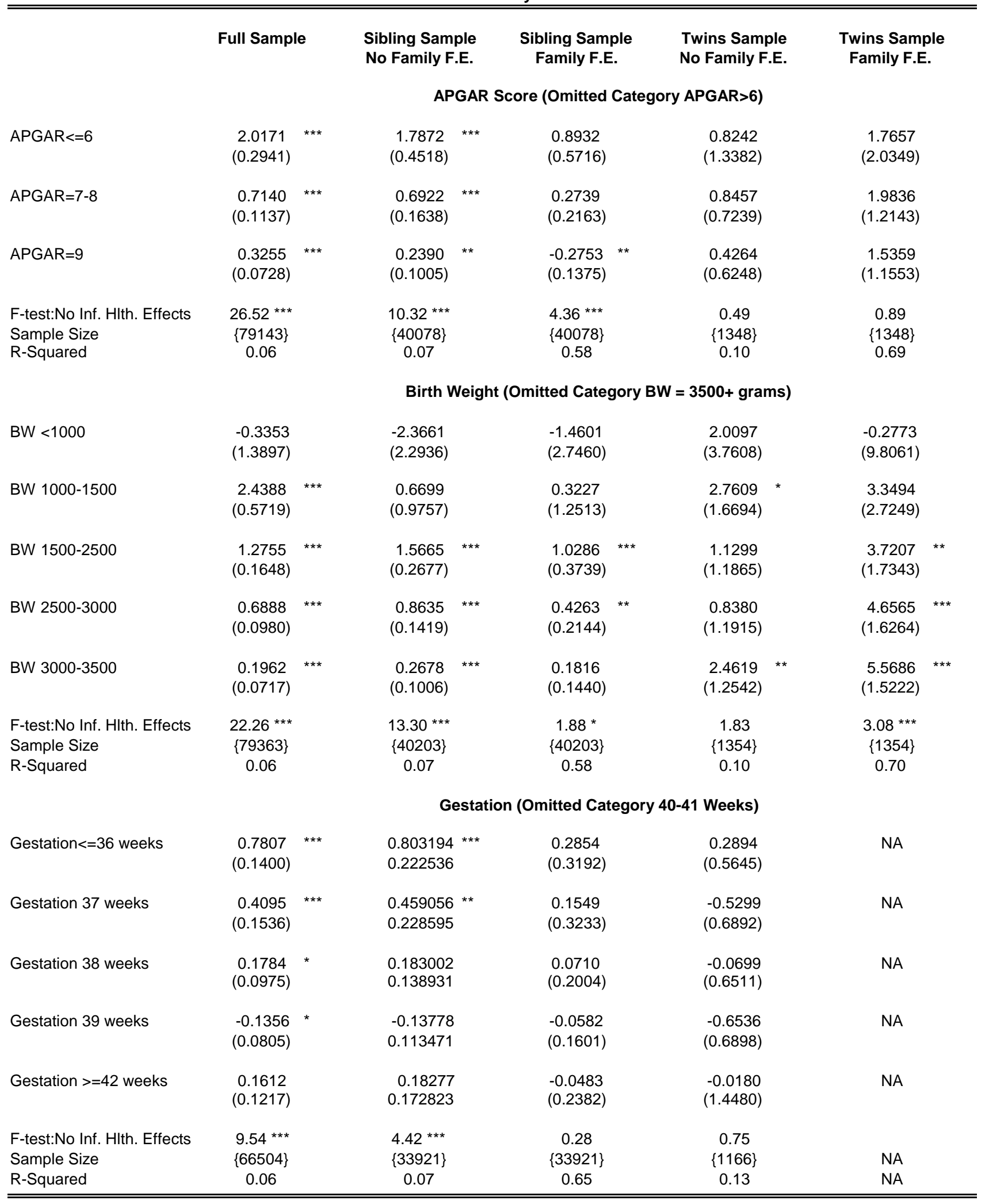

All regression models include additional fixed effects for mother's martial status, gender of child, and family sibling size dummies for the birth order of the child within each family size. One, two, and three asteriks indicate statistical significance at the 10,5 , and 1 percent levels respectively. 
Table 11

Estimated Effects of Infant Health at Birth on Infant Mortality

Close Siblings as Compared to All Siblings, With and Without Family Fixed Effects

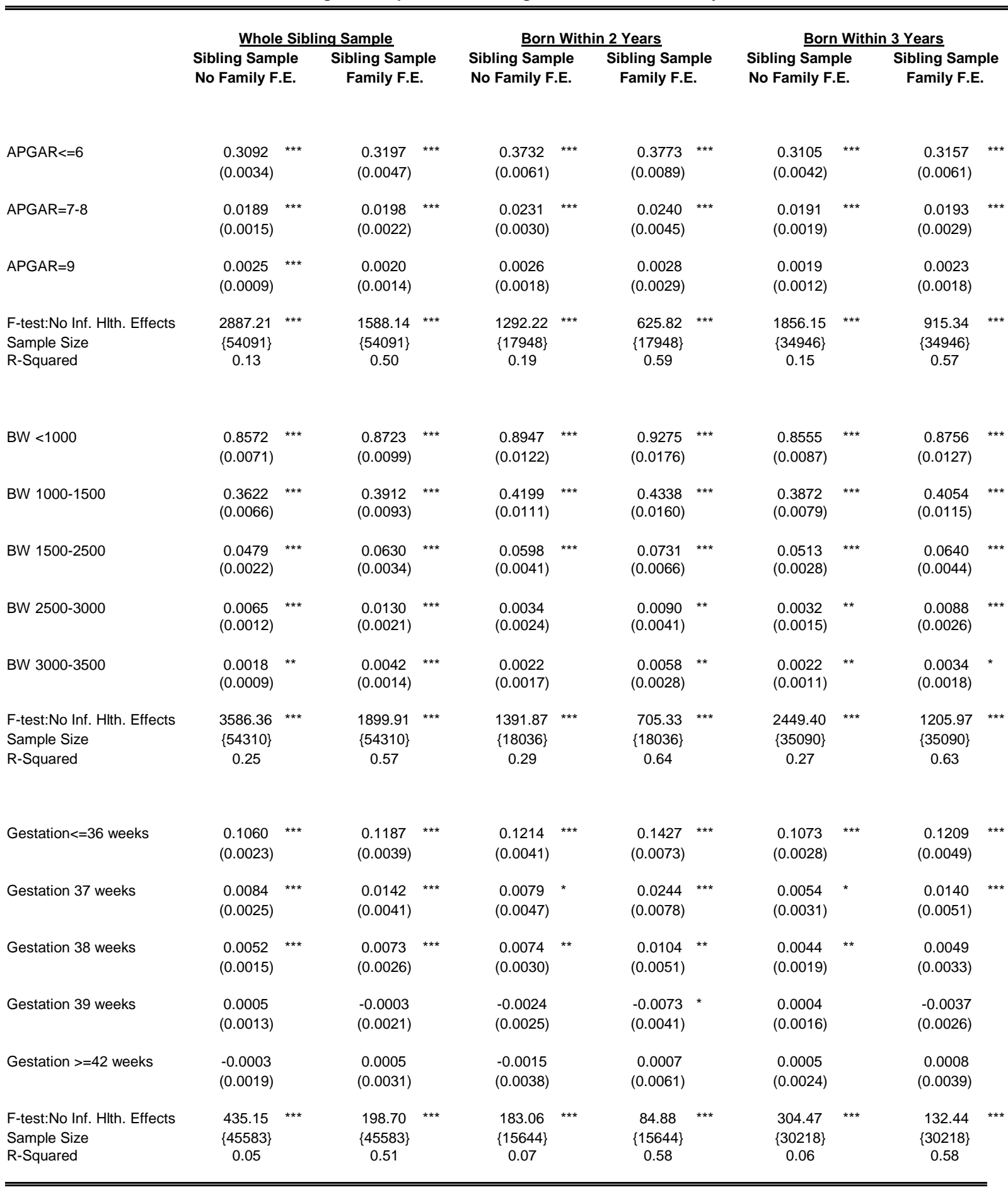

All regression models include additional fixed effects for mother's martial status, gender of child, and family sibling size dummies for the birth order of the child within each family size. One, two, and three asteriks indicate statistical significance at the 10,5 , and 1 percent levels respectively. 
Table 12

Estimated Effects of Infant Health at Birth on Reaching Grade 12 by Age 17

Close Siblings as Compared to All Siblings, With and Without Family Fixed Effects

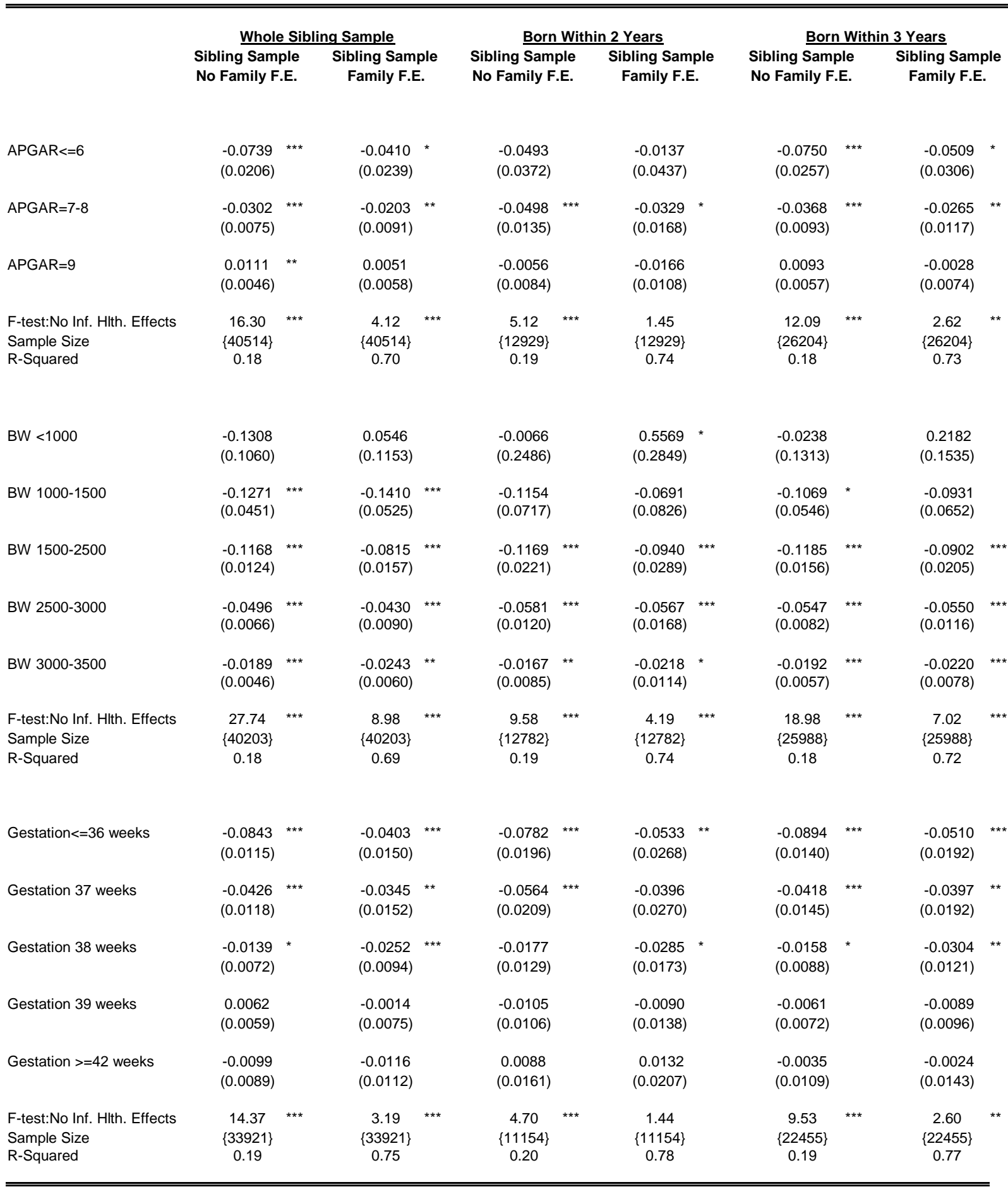

All regression models include additional fixed effects for mother's martial status, gender of child, and family sibling size dummies for the birth order of the child within each family size. One, two, and three asteriks indicate statistical significance at the 10,5 , and 1 percent levels respectively. 
Table 13

Estimated Effects of Infant Health at Birth on Months on Social Assistance

Close Siblings as Compared to All Siblings, With and Without Family Fixed Effects

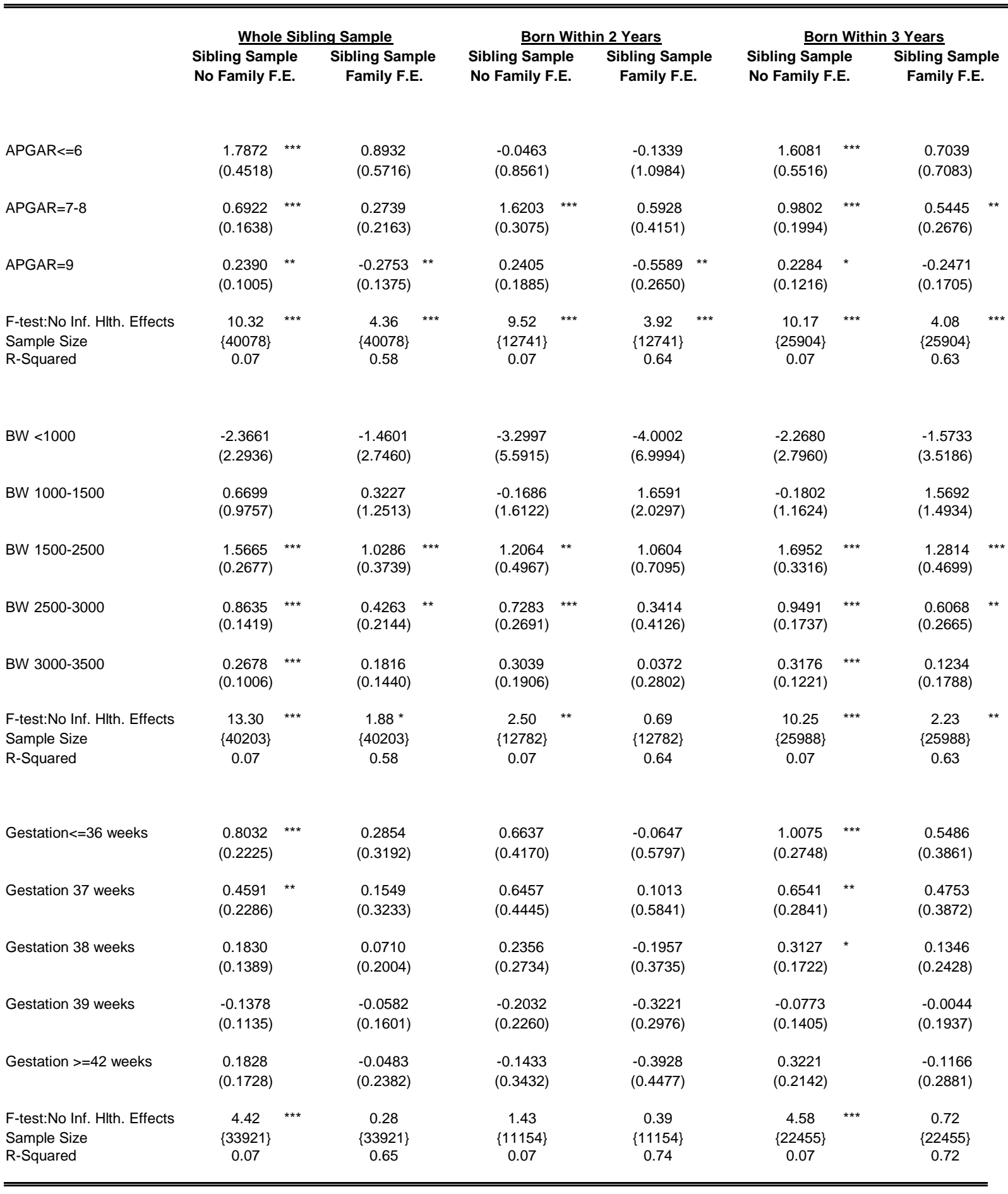

All regression models include additional fixed effects for mother's martial status, gender of child, and family sibling size dummies for the birth order of the child within each family size. One, two, and three asteriks indicate statistical significance at the 10,5 , and 1 percent levels respectively. 
Table 14

Estimated Effects of Infant Health at Birth on Infant Mortality (Death within One Year of Birth) With and Without Family Fixed Effects

By Parental Residence Income Quintiles

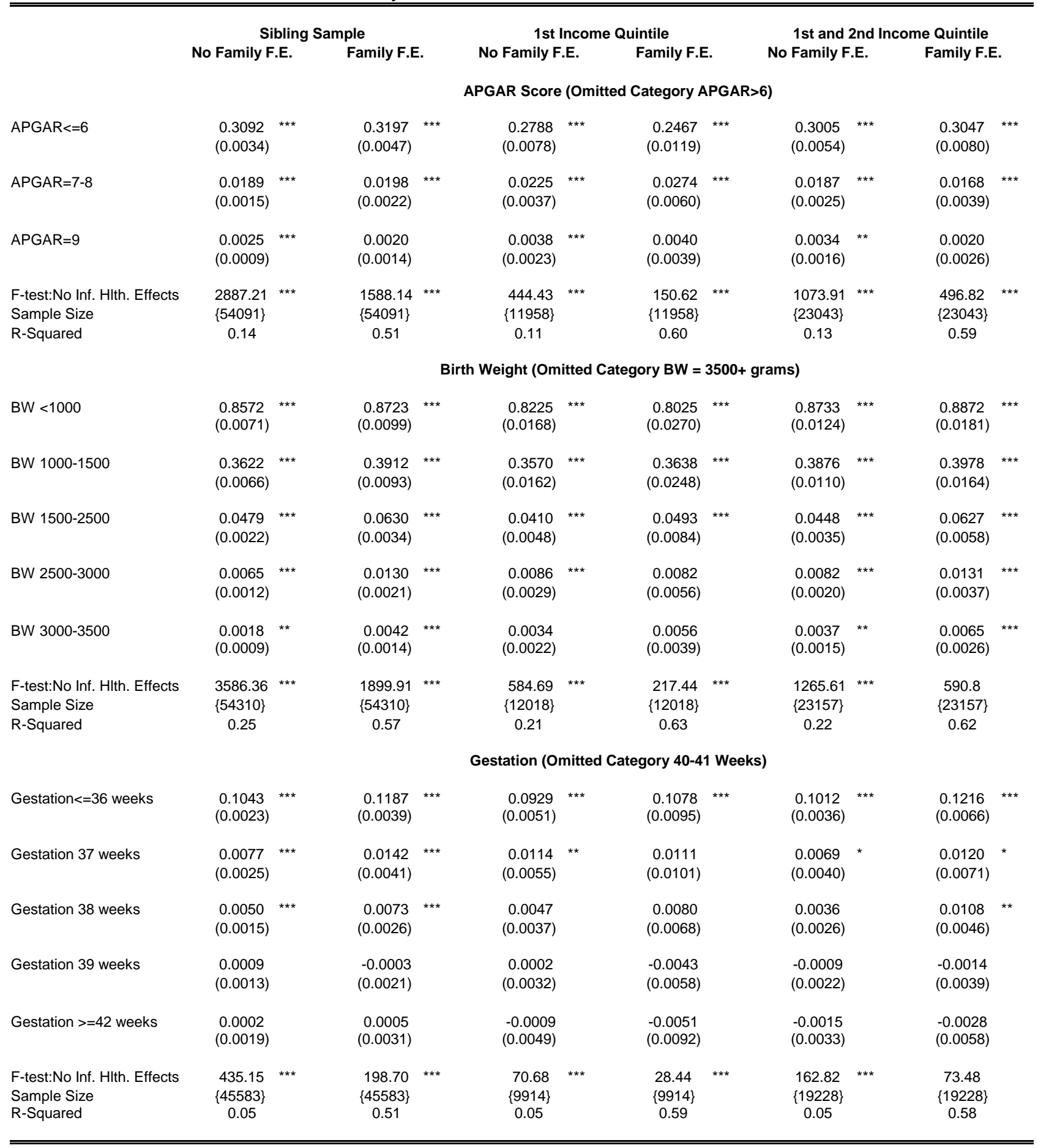

All regression models include additional fixed effects for mother's martial status, gender of child, and family sibling size dummies for the birth order of the child within each family size. One, two, and three asteriks indicate statistical significance at the 10,5 , and 1 percent levels respectively. 
Table 15

Estimated Effects of Infant Health at Birth on Grade 12 Attainment by Age 17 With and Without Family Fixed Effects

By Parental Residence Income Quintiles

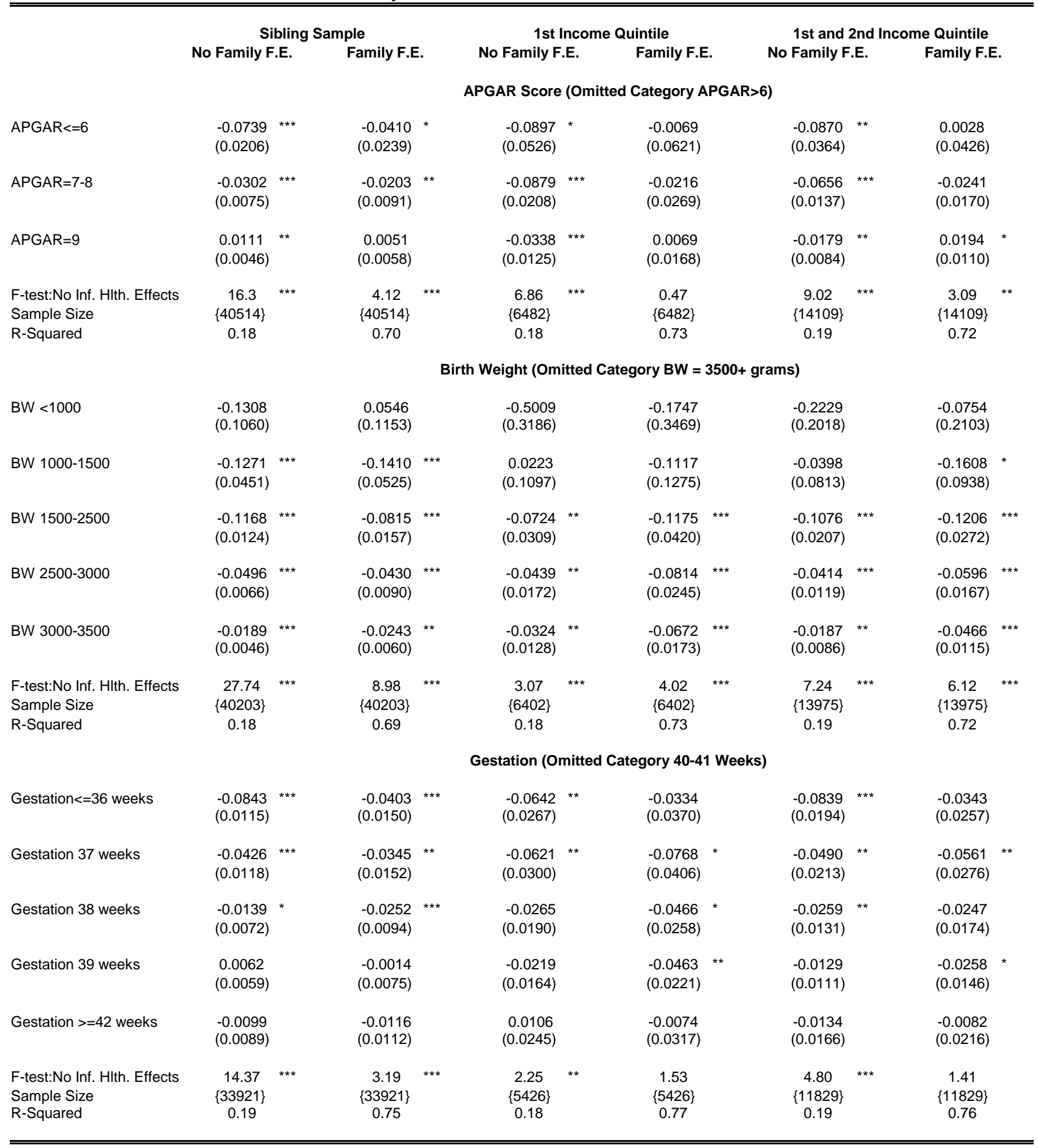

All regression models include additional fixed effects for mother's martial status, gender of child, and family sibling size dummies for the birth order of the child within each family size. One, two, and three asteriks indicate statistical significance at the 10,5 , and 1 percent levels respectively. 
Table 16

Estimated Effects of Infant Health at Birth on Social Assistance Take-up (By months) With and Without Family Fixed Effects

By Parental Residence Income Quintiles

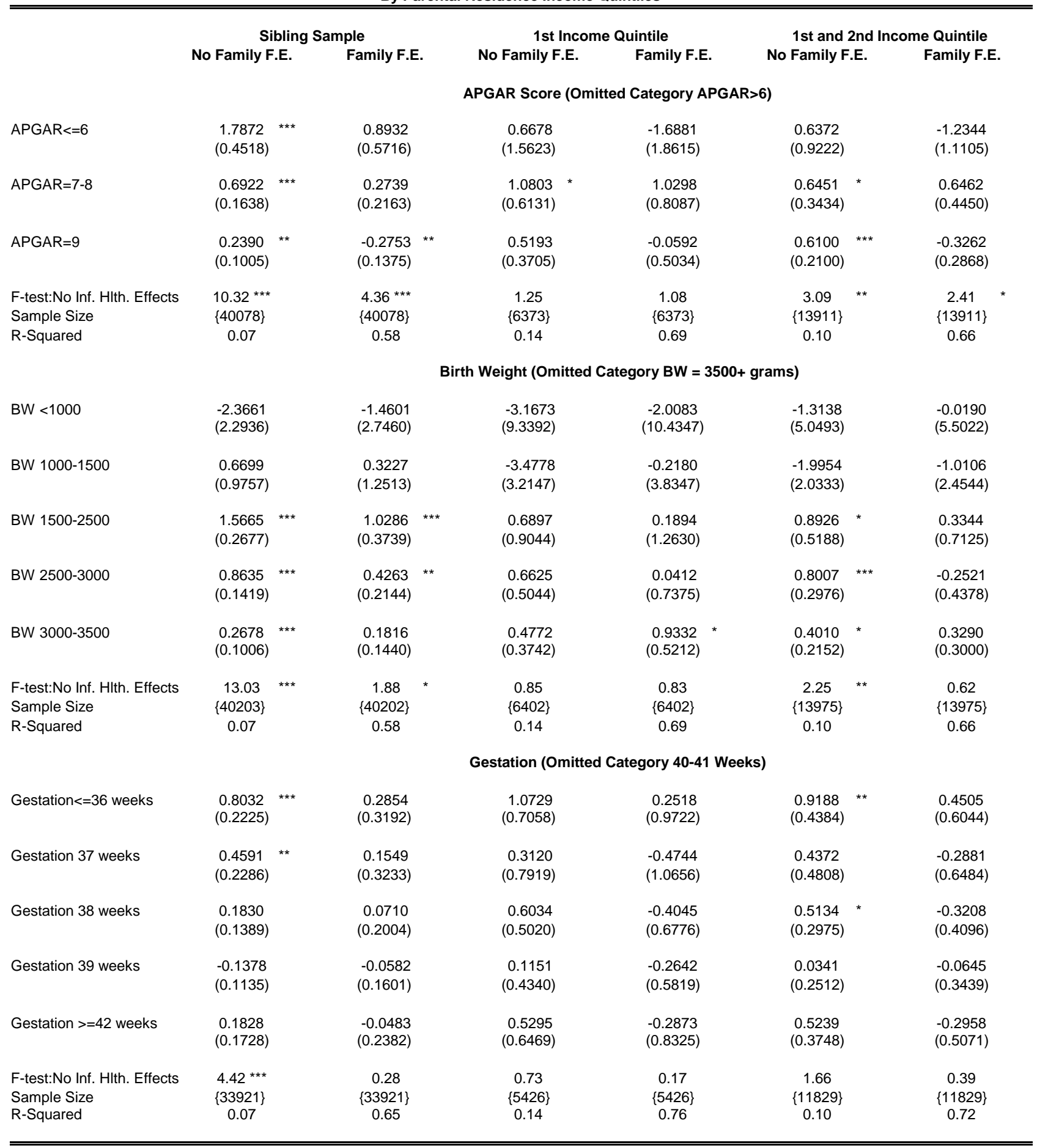

All regression models include additional fixed effects for mother's martial status, gender of child, and family sibling size dummies for the birth order of the child within each family size. One, two, and three asteriks indicate statistical significance at the 10,5 , and 1 percent levels respectively. 
Table A1

Estimated Effects of Infant Health at Birth on Infant Mortality (Death within One Year of Birth) With and Without Family Fixed Effects

Linear Model

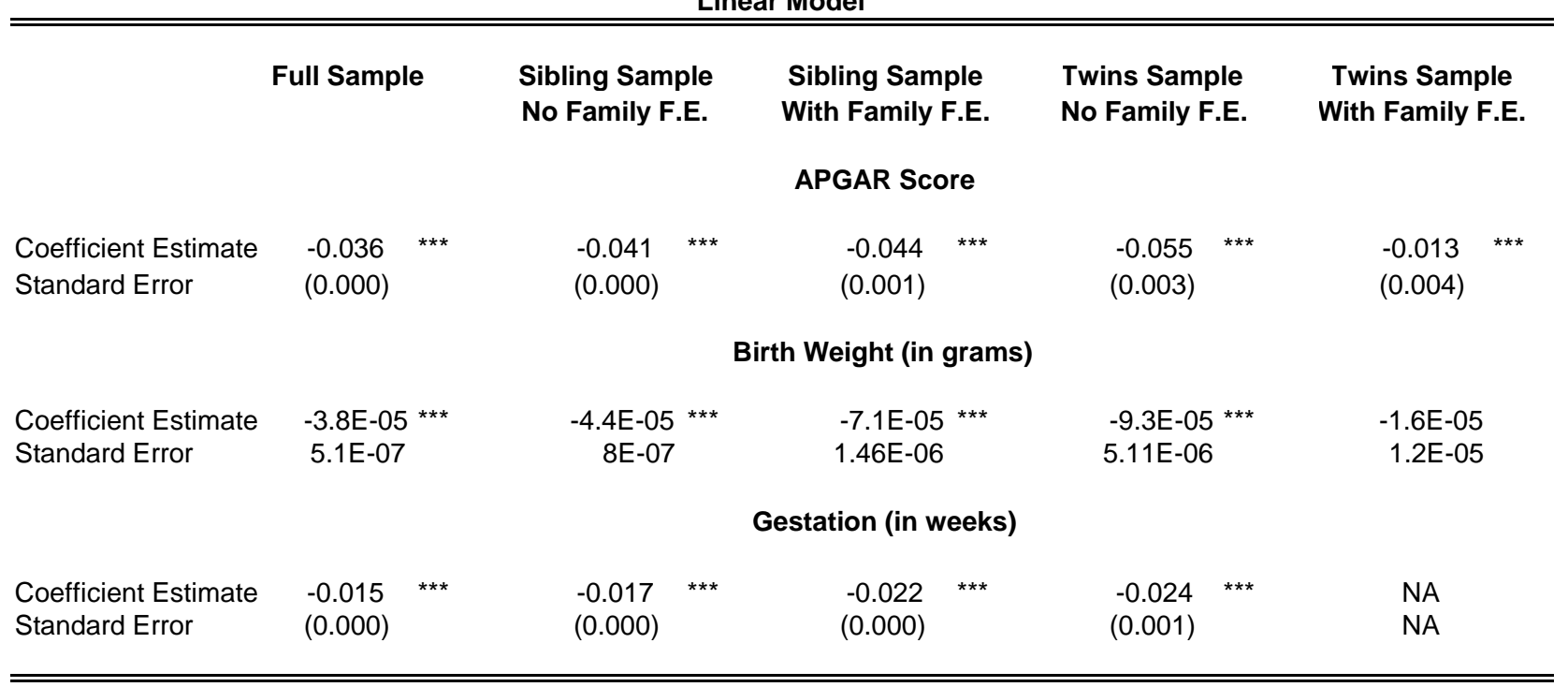

All regression models include additional fixed effects for mother's martial status, mother's age at child's birth, gender of child, and family sibling size dummies for the birth order of the child within each family size. One, two, and three atericies indicate statistical significance at the 10,5 , and 1 percent levels respectively. 
Table A2

Estimated Effects of Infant Health at Birth on Physician Visits

With and Without Family Fixed Effects

Linear Model

Mean Age:

\section{Full Sample Sibling Sample No Family F.E.}

\author{
Sibling Sample \\ With Family F.E.
}

Twins Sample No Family F.E.

Twins Sample

With Family F.E.

\section{APGAR Score}

\author{
Coefficient Estimate
}

$-0.3091^{* * *}$
$(0.0569)$

Standard Error

(0.0569)

$-0.2164^{* * *}$

(0.0793)
0.0459
(0.0912)

-0.1233
$(0.2705)$

$-0.1306$

(0.3491)

Birth Weight (in grams)

Coefficient Estimate $\quad-1.62 \mathrm{E}-04$ * $\quad-5.32 \mathrm{E}-05$

Standard Error

8.46E-05

1.19E-04

-8.26E-05

1.77E-04

$-1.27 \mathrm{E}-03$ *

5.27E-04

$-1.86 \mathrm{E}-04$

9.94E-04

\section{Gestation (in weeks)}

Coefficient Estimate Standard Error
0.0073

$(0.0408)$

\begin{abstract}
0.0486
(0.0548)
\end{abstract}

$-0.0952$

(0.1120)
NA

NA

All regression models include additional fixed effects for mother's martial status, mother's age at child's birth, gender of child, and family sibling size dummies for the birth order of the child within each family size. One, two, and three atericies indicate statistical significance at the 10,5 , and 1 percent levels respectively. 
Table A3

Estimated Effects of Infant Health at Birth on Language Arts Score

With and Without Family Fixed Effects

Linear Model

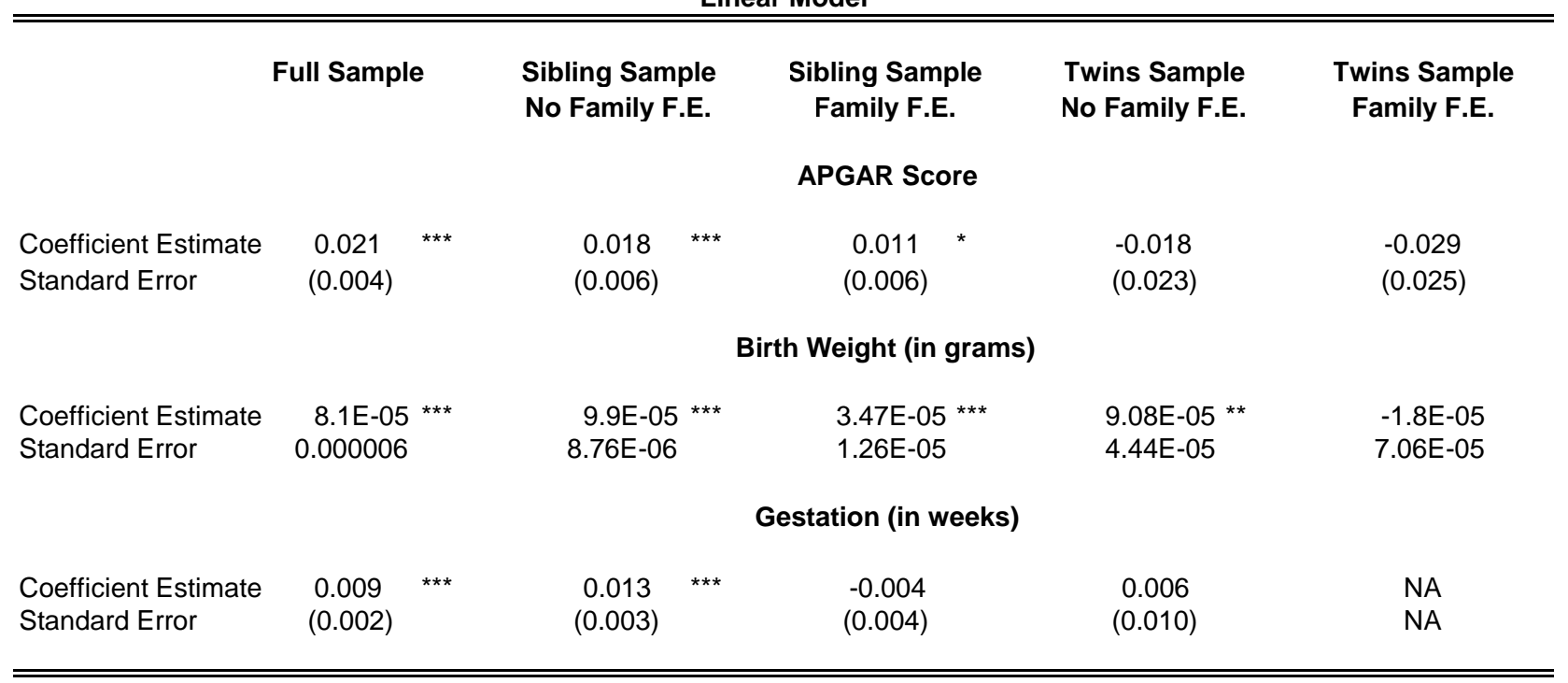

All regression models include additional fixed effects for mother's martial status, mother's age at child's birth, gender of child, and family sibling size dummies for the birth order of the child within each family size. One, two, and three atericies indicate statistical significance at the 10,5 , and 1 percent levels respectively. 
A4

Estimated Effects of Infant Health at Birth on Attaining Grade 12 by Age 17

With and Without Family Fixed Effects

Linear Model

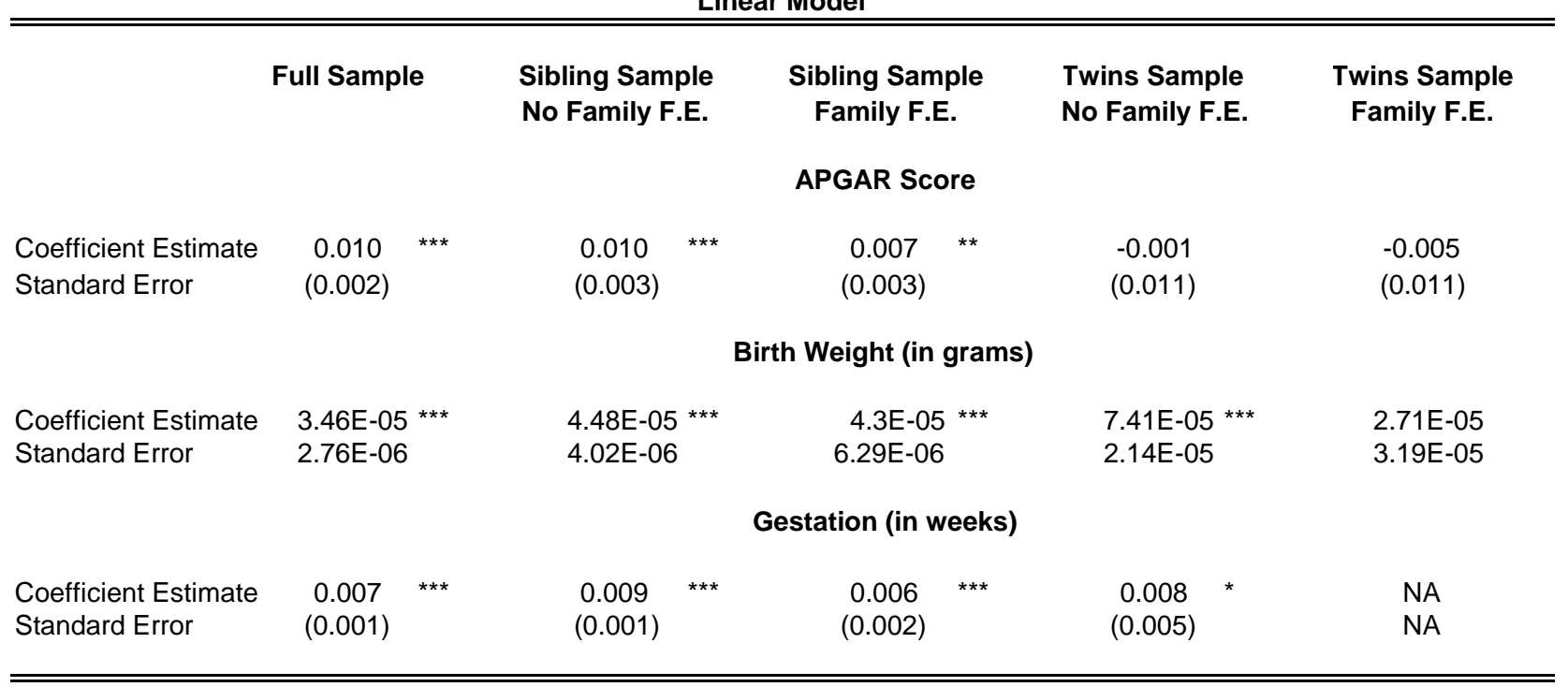

All regression models include additional fixed effects for mother's martial status, mother's age at child's birth, gender of child, and family sibling size dummies for the birth order of the child within each family size. One, two, and three atericies indicate statistical significance at the 10,5 , and 1 percent levels respectively. 
Table A5

Estimated Effects of Infant Health at Birth on Graduation on Time

With and Without Family Fixed Effects (1982 and later births only)

Linear Model

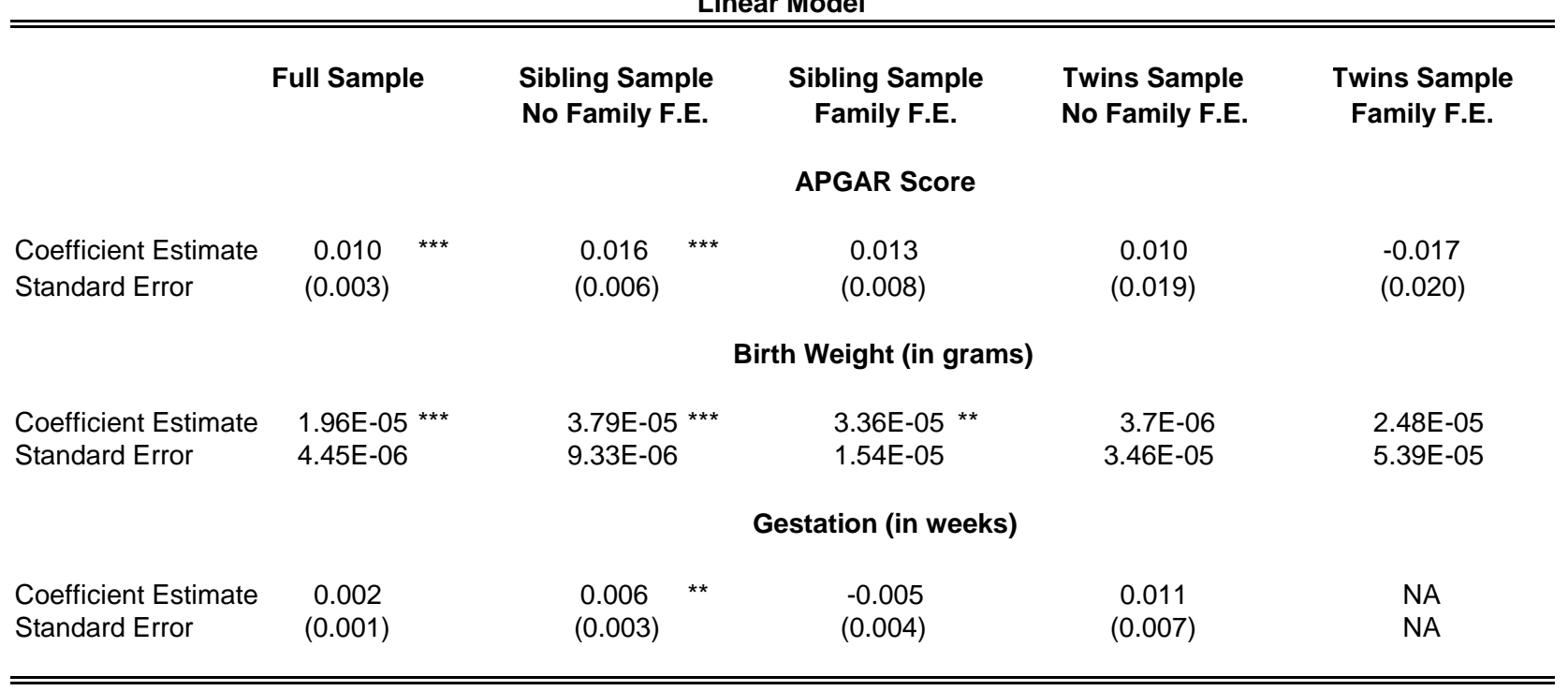

All regression models include additional fixed effects for mother's martial status, mother's age at child's birth, gender of child, and family sibling size dummies for the birth order of the child within each family size. One, two, and three atericies indicate statistical significance at the 10,5 , and 1 percent levels respectively. 
Table A6

Estimated Effects of Infant Health at Birth on Social Assistance (yes/no) After Age 18 With and Without Family Fixed Effects

Linear Model

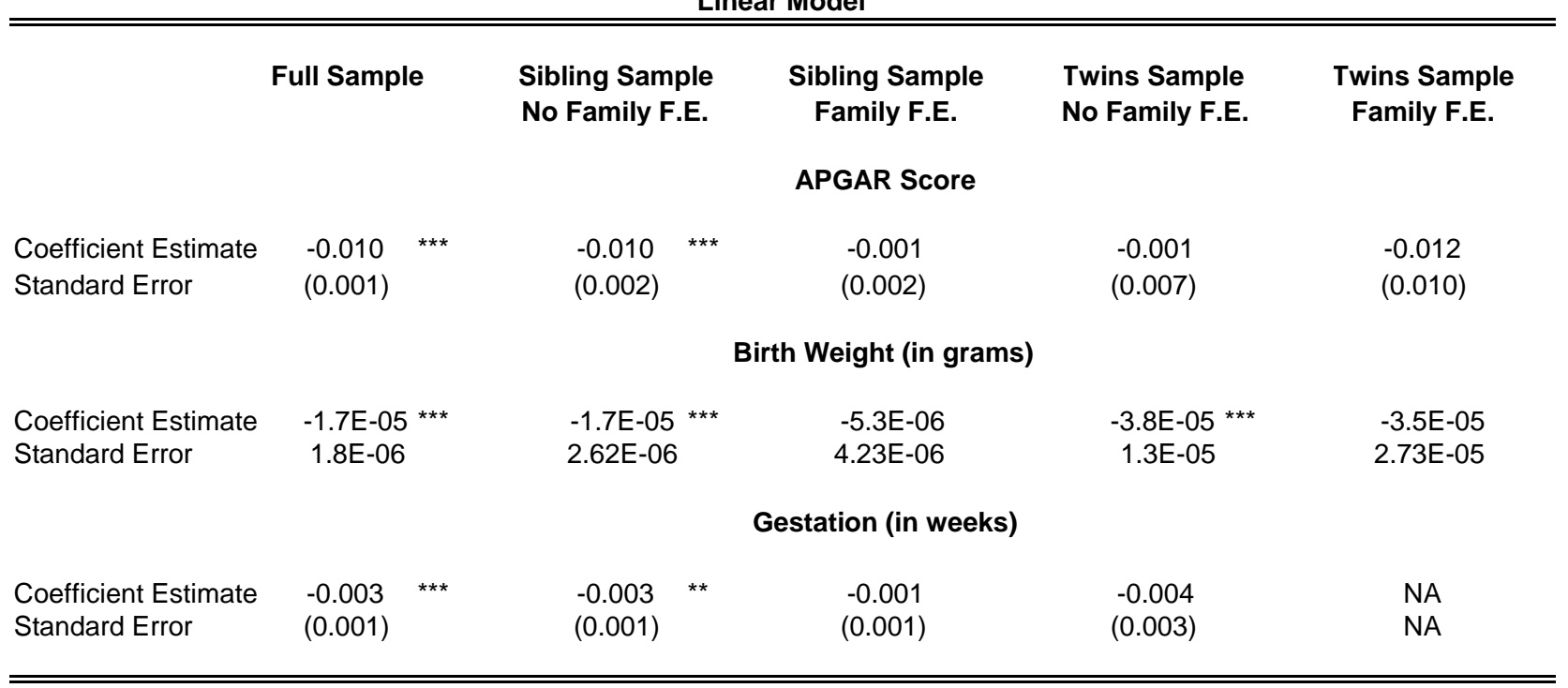

All regression models include additional fixed effects for mother's martial status, mother's age at child's birth, gender of child, and family sibling size dummies for the birth order of the child within each family size. One, two, and three atericies indicate statistical significance at the 10,5 , and 1 percent levels respectively. 
Table A7

Estimated Effects of Infant Health at Birth on Social Assistance (months) After Age 18 With and Without Family Fixed Effects

Linear Model

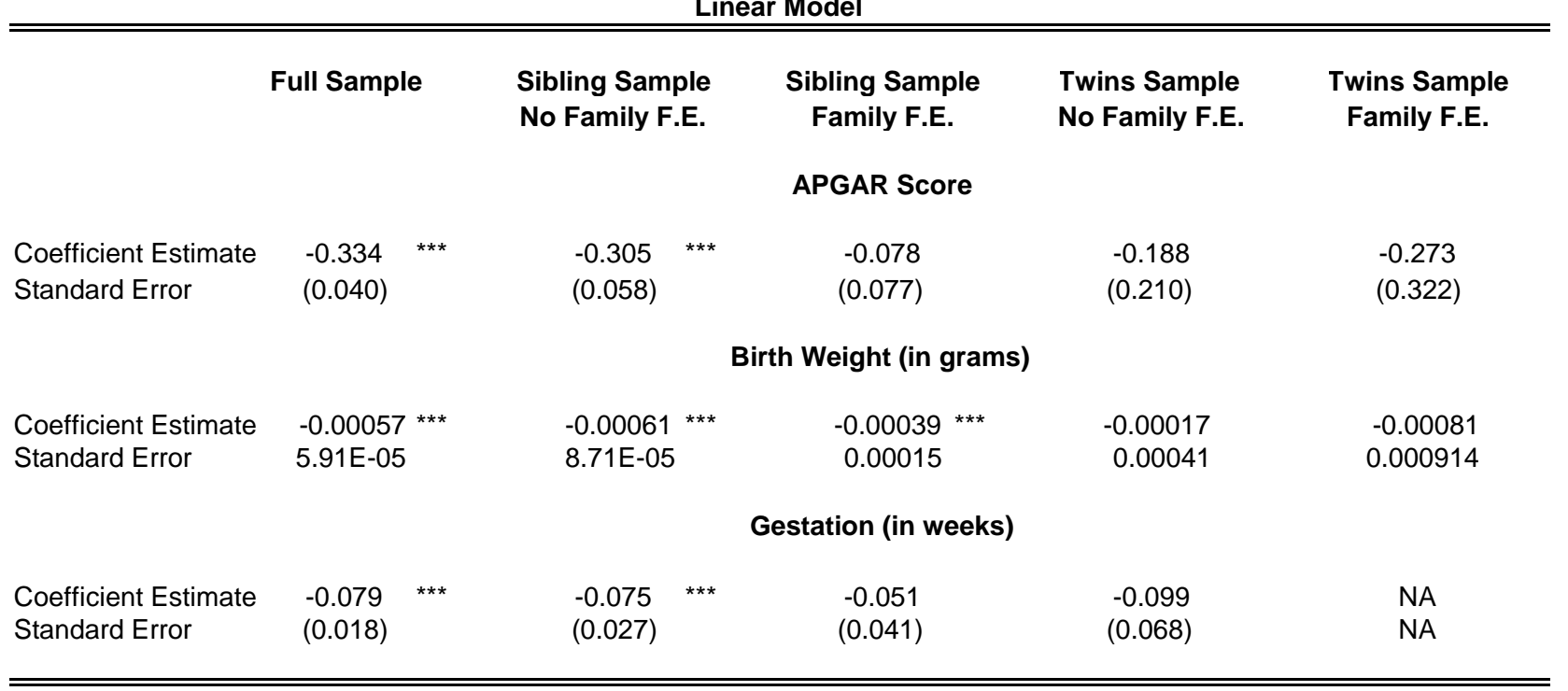

All regression models include additional fixed effects for mother's martial status, mother's age at child's birth, gender of child, and family sibling size dummies for the birth order of the child within each family size. One, two, and three atericies indicate statistical significance at the 10,5 , and 1 percent levels respectively. 